\title{
Partitioning the genetic architecture of amyotrophic lateral sclerosis
}

Iris J. Broce, ${ }^{1 *}$ Chun C. Fan, ${ }^{2}$ Nicholas T. Olney, ${ }^{3}$ Catherine Lomen-Hoerth,${ }^{3}$ Steve Finkbeiner, ${ }^{3}$ Nazem Atassi, ${ }^{4}$ Merit E. Cudkowicz, ${ }^{4}$ Sabrina Paganoni, ${ }^{5}$ Jennifer S. Yokoyama, ${ }^{3}$ Aimee Kao, ${ }^{3}$ William P. Dillon, ${ }^{1}$ Christine M. Glastonbury, ${ }^{1}$ Christopher P. Hess, ${ }^{1}$ Wouter van Rheenen, ${ }^{6}$ Jan H. Veldink, ${ }^{6}$ Ammar Al-Chalabi, ${ }^{7}$ Ole A. Andreassen, ${ }^{8}$ Anders M. Dale, ${ }^{2,9,10}$ William W. Seeley, ${ }^{3}$ Leo P. Sugrue,${ }^{1}$ Aaron Ofori-Kuragu, ${ }^{11}$ Celeste M. Karch, ${ }^{11}$ Bruce L. Miller, ${ }^{3 *}$ and Rahul S. Desikan ${ }^{1 *}$

${ }^{1}$ Department of Radiology and Biomedical Imaging, University of California, San Francisco, CA, USA.

${ }^{2}$ Department of Cognitive Sciences, University of California, San Diego, La Jolla, CA, USA. ${ }^{3}$ Department of Neurology, University of California, San Francisco, CA, USA.

${ }^{4}$ Department of Neurology, Massachusetts General Hospital, Harvard Medical School, Boston, MA, USA.

${ }^{5}$ Neurological Clinical Research Institute (NCRI) Massachusetts General Hospital (MGH) Boston, MA, USA.

${ }^{6}$ Department of Neurology, Brain Center Rudolf Magnus, University Medical Center Utrecht, Utrecht, the Netherlands.

${ }^{7}$ King's College London, Maurice Wohl Clinical Neuroscience Institute, Department of Basic and Clinical Neuroscience and Department of Neurology, King's College Hospital, London, UK. ${ }^{8}$ Norwegian Centre for Mental Disorders Research (NORMENT), Institute of Clinical Medicine, University of Oslo, Oslo, Norway.

${ }^{9}$ Department of Radiology, University of California, San Diego, La Jolla, CA, USA

${ }^{10}$ Department of Neurosciences, University of California, San Diego, La Jolla, CA, USA

${ }^{11}$ Department of Psychiatry, Washington University in St Louis, St Louis, MO, USA.

* rahul.desikan@ucsf.edu (RSD), iris.broce@ucsf.edu (IJB), bruce.Miller@ucsf.edu (BLM) 


\begin{abstract}
The genetic basis of sporadic amyotrophic lateral sclerosis (ALS) is not well understood. Using large genome-wide association studies and validated tools to quantify genetic overlap, we systematically identified single nucleotide polymorphisms (SNPs) associated with ALS conditional on genetic data from 65 different traits and diseases from $>3$ million people. We found strong genetic enrichment between ALS and a number of disparate traits including frontotemporal dementia, coronary artery disease, C-reactive protein, celiac disease and memory function. Beyond $C 9 O R F 72$, we detected novel genetic signal within numerous loci including GIPC1, ELMO1 and COL16A and confirmed previously reported variants, such as ATXN2, KIF5A, UNC13A and MOBP. We found that ALS variants form a small-world co-expression network characterized by highly inter-connected 'hub' genes. This network clustered into smaller sub-networks, each associated with a unique function. Altered gene expression of several subnetworks and hubs was over-represented in neuropathological samples from ALS patients and SOD1 G93A mice. Our collective findings indicate that the genetic architecture of ALS can be partitioned into distinct components where some genes are highly important for developing disease. These findings have implications for stratification and enrichment strategies for ALS clinical trials.
\end{abstract}




\section{Introduction}

Sporadic amyotrophic lateral sclerosis (ALS) is a fatal neurodegenerative disease characterized by progressive muscle paralysis from selective loss of upper and lower motor neurons. Spreading rapidly, ALS can lead to respiratory failure and death in 3-5 years ${ }^{1}$. Given the paucity of disease modifying treatments, elucidating the genetic basis of ALS can delineate putative pharmacological targets and highlight molecular mechanisms underlying disease. Importantly, refining the genetic landscape of ALS can inform cohort stratification and enrichment strategies for clinical trials.

ALS is increasingly recognized as a complex disorder with an incompletely understood genetic architecture. Prior work suggests that sporadic ALS is genetically characterized by a few rare variants, each explaining a substantial portion of the inherited risk (oligogenic) $)^{2-4}$. However, more recent evidence indicates that low-risk, common variants underlie ALS (polygenic) ${ }^{5}$. Importantly, several ALS-associated variants have been implicated in other diseases suggesting genetic pleiotropy ${ }^{6-8}$. Furthermore, it is not known whether certain ALS genes are more important than others for influencing disease etiology.

Here, our goal was to elucidate the genetic architecture of ALS by leveraging statistical power from large GWAS from 65 distinct traits and diseases. Using these methods, we have discovered novel genetic risk loci and shown abundant genetic pleiotropy between several neurodegenerative diseases including ALS, FTD, progressive supranuclear palsy (PSP), corticobasal degeneration (CBD), Parkinson's disease (PD), and Alzheimer's disease (AD) ${ }^{8-12}$. 


\section{Results}

\section{Selective shared genetic risk between ALS and 65 distinct traits}

Using previously published stratified FDR methods (see Methods), we assessed genetic overlap between ALS and 65 distinct traits and diseases. We identified genetic enrichment in ALS SNPs across different levels of significance with 65 distinct traits and diseases (Fig. 1). Consistent with prior work ${ }^{8}$, we found that the highest level of pleiotropic enrichment was between ALS and FTD (700-fold enrichment). Surprisingly, we also found robust genetic enrichment in ALS SNPs as a function of coronary artery disease (CAD; 300-fold enrichment), memory (225-fold enrichment), C-reactive protein (CRP; 50-fold enrichment), and PSP (50-fold enrichment). We found weaker genetic enrichment with celiac disease (CeD), CBD, body mass index (BMI), rheumatoid arthritis (RA), schizophrenia (SCZ), verbal numeric reasoning (VNR), and putamen volume (PUT). We found no enrichment between ALS and the other phenotypes. We note that these analyses reflect genetic enrichment after removing all SNPs within chromosome 9 .

To identify novel ALS risk loci, we used a stratified approach. First, we computed conditional FDR, a statistical framework that is well suited for gene detection ${ }^{9,13}$. Conditional FDR analysis at a FDR p-value $<0.05$ revealed 180 SNPs across 21 chromosomes (Fig. 2, Supplementary Table 1). Next, we performed extensive LD analyses to identify the variants underlying the genetic signals (see Supplemental Information). After accounting for LD, we identified 89 risk loci and annotated each ALS risk SNP with the closest gene(s), resulting in a total of 92 closest genes (Fig. 2, Table 1). Of these, 30 SNPs were either previously reported or were in LD with a previously reported SNP (Table 1, Supplementary Fig. 1). An additional 59 SNPs were novel or were not in LD with SNPs within previously reported loci (Table 1, 
Supplementary Fig. 1). We found independent hits from SNPs previously reported within CRIM1, NAF1, TNIPI, PARKIN, ELP3, MRSA, C9ORF72, PCDH9, A2BP1, and CPNE7 (Table $1)$.

To determine whether the ALS risk genes were associated with a single trait or multiple traits, we plotted the minimum conditional FDR associated with all traits and closest genes. As shown in Supplementary Fig. 2, across all 65 traits and diseases, we found that the ALS risk variants are associated with multiple traits and diseases. Genetic variants within C9ORF72 were identified on 46 traits. Genetic variants within KIAA0524 (also known as SARM1) were identified on 64 traits, $U N C 13 A$ on 62 traits, $M O B 3 B$ on 58 traits, TBK1 on 34 traits, and $C A T$ and $C 210 R F 2$ on 27 traits.

These findings suggest that ALS has a polygenic component where several genes potentially contribute to disease risk. Genetic pleiotropy with traits like FTD and CAD can be leveraged for ALS gene detection. Importantly, there are several ALS susceptibility loci that are also associated with numerous other traits and diseases.

\section{cis-eQTL expression}

To determine the functional effects of the ALS pleiotropic risk SNPs, we evaluated cisexpression quantitative loci (cis-eQTL) in human brains free of neuropathology (Supplementary Table 2). In total, the ALS risk SNPs produced significant cis-eQTLs (below $1.5 \times 10^{-3}$ ) within

41 genes. Of these, SNPs within SMARCA2, GGNBP2, NUP50, and TNIP1 showed overlapping annotation between the eQTL and the closest genes. Thirteen SNPs showed significant ciseQTLs with multiple genes. 


\section{Biological networks associated with ALS genetic risk genes}

Using GeneMANIA (www.genemania.org), an online web-portal for bioinformatic assessment of gene networks ${ }^{14}$, we conducted a network analysis to explore the interaction and co-expression patterns associated with the ALS risk genes defined as the combination of the 1) closest genes to the SNP and 2) functional genes (i.e., SNPs with significant cis-eQTLs). We found that a large number of these genes showed physical protein-protein interactions (42.93\%), were co-expressed (29.33\%), and showed genetic interactions (13.28\%) (Fig. 3). Few ALS genetic risk genes shared pathways $(9.36 \%)$, were co-localized $(2.60 \%)$, or predicted functional interactions between genes based on orthology (2.50\%) (Supplementary Table 3).

\section{Properties of the ALS biological networks}

We assessed the network structure of the physical protein-protein interaction network, coexpression network, and genetic interactions network. Specifically, we asked whether some genes play a more influential role than others. Most complex networks have a small-world property characterized by relatively short paths between any pair of nodes (genes) ${ }^{15}$. In smallworld networks, perturbing any given node is thought to also perturb neighboring nodes and the entire network in general. Quantitatively, a network is considered small-world if its "smallworldness" index is higher than one (a stricter rule is small-worldness $>=3)^{16}$. Further, the clustering coefficient for the target small-world network should be higher than the clustering coefficient of a comparable random network. Also, the average shortest path length of the target network should be similar or higher (but not substantially higher) than a comparable random network. 
First, we evaluated the degree to which each network assumed a small-work network structure. The co-expression interaction network consisted of 95 nodes and 132 edges, had a small-world index of 6.06, a diameter of 13 , and average shortest path length of 5.12. The clustering coefficient was 0.102 , which is higher than the clustering coefficient of a random graph with the same number of indices $(0.031)$. The physical protein-protein interaction network consisted of 85 nodes and 41 edges, had a small-world index of 4.43, a diameter of 5, and average shortest path length of 82.03 . The clustering coefficient was 0.326 , which is also higher than the clustering coefficient of a random network with the same number of indices $(0.06)$. Lastly, the genetic interaction network consists of 98 nodes and 472 edges, had a low smallworld network index of 1.11, a diameter of 5, and average shortest path length of 2.33. The clustering coefficient for this network (0.197) was similar to the clustering coefficient of a random network with the same number of indices (0.192). Of the three networks, the coexpression network showed robust small-world network properties - the physical protein-protein interactions network had a substantially large shortest path length and the genetic-interactions network clustering coefficient did not differ from random. Therefore, in subsequent network analysis we focused on the co-expression network.

To further assess the structure of the co-expression network, we evaluated various network centrality measures, including degree centrality, eigenvector centrality, and edgebetweenness centrality. Centrality network measures define how important each node is within a given network. The degree centrality is the number of edges connected to a node. Eigenvector centrality is the extent to which a node is connected to other highly influential "hub" nodes. Edge-betweenness centrality is the extent to which a node lies on the shortest path between other nodes (see Methods). Fig. 4a shows the co-expression network. The size of each node is defined 
by its eigenvector centrality (EC) value. Genes with a high EC and high degree centrality can be characterized as hubs ${ }^{15,16}$. Within the co-expression network, genes with high degree centrality (Supplementary Fig. 3) and high EC (Supplementary Fig. 4) were GIPCl (n=8, EC=1.00), $\operatorname{ELMO1}(\mathrm{n}=6, \mathrm{EC}=0.994), U G C G(\mathrm{n}=7, \mathrm{EC}=0.978), S M A R C A 2(\mathrm{n}=6, \mathrm{EC}=0.924), A T X N 2$ $(\mathrm{n}=6, \mathrm{EC}=0.765)$, and SETD2 $(\mathrm{n}=6, \mathrm{EC}=0.729)$. In addition to these, DOCK2 $(\mathrm{n}=5, \mathrm{EC}=$ 0.809), KIAA0917/SCFD1 $(\mathrm{n}=5, \mathrm{EC}=0.752), \operatorname{HTR} 2 A(\mathrm{n}=4, \mathrm{EC}=0.695)$, and COL16A1 $(\mathrm{n}=5$, $\mathrm{EC}=0.645)$ were also highly influential based on EC values.

Next, we explored whether the co-expression network could be partitioned into potentially meaningful subnetworks (Fig. 4a,b). The network was partitioned into subnetworks by removing edges with high edge-betweenness centrality (see Methods). The result was a hierarchical map, called a dendrogram (Fig. 4b). We identified a total of 8 clusters. Five clusters contained the most influential hub genes. The yellow cluster contained 5 hub genes (HTR2A, GIPC1, SMARCA2, ELMO1, and DOCK2). The purple cluster contained two hub genes (UGCG and SETD2), and the teal, orange, and red clusters contained a single hub gene (COL16A1, ATXN2, KIAA0917, respectively).

Collectively, these findings suggest that ALS genes that are co-expressed form networks with small-world properties and can be further partitioned into different clusters. Importantly, specific genes, such as GIPC1 and ATXN2, act like hubs, characterized by a high degree of connectivity with other genes; perturbing these hub genes may disrupt the entire network.

\section{Biological pathways associated with ALS risk genes within co-expression network}

We used bioinformatics approaches to identify distinct and common biological pathways associated with the 8 subnetworks within the ALS co-expression network (see Methods). The top 
5 functional annotations for each subnetwork are shown in Fig. 5a. The blue subnetwork was enriched for developmental processes, including neuron projection development and regulation of cell growth. The gray subnetwork was enriched for apoptotic signaling pathway, cell death, and protein phosphorylation. The green subnetwork was enriched for cell-cell signaling, response to external stimuli, and metabolic processes. The purple cluster was enriched for vascular morphology and angiogenesis. The orange, red, teal, and yellow subnetworks were enriched for vesicle-mediated processes. Lastly, the orange and red networks were also enriched for organelle membrane fusion and disassembly processes, and the teal subnetwork was also enriched for oxidative reduction and androgen metabolic processes.

Further, we explored whether genes within the distinct subnetworks were selectively enriched for neuron-specific biological, chemical, or molecular processes. As shown in Fig. 5b, the blue, green, teal, and yellow subnetworks were selectively enriched for neuronal processes, particularly involved in neuron differentiation, projection, guidance, and development. We also found that several hub genes within the yellow subnetwork (GIPC1, SMARC2, HTR2A) were over-represented in these processes (Supplementary Fig. 5). Taken together, these findings highlight that the ALS co-expression subnetworks are involved in distinct and overlapping biological pathways.

\section{Differential expression of ALS risk genes in tissue from ALS patients and SOD1 G93A}

\section{transgenic mice}

We investigated whether particular clusters or hub genes were enriched in pathological samples from ALS patients. To do this, we assessed the differential expression of genes within the ALS co-expression network in the gray matter of motor neurons isolated from spinal cords of 
patients with familial and sporadic ALS and controls (Fig. 6a, see Methods). We found that 2 genes within the teal subnetwork (COL16A1 and GPX3) and one gene within the purple subnetwork $(U G C G)$ were differentially expressed in tissue from controls compared to familial ALS patients. COL16Al was also differentially expressed in tissue from controls compared to sporadic ALS patients. Importantly, COL16Al and $U G C G$ are hub genes.

To validate the genes identified in ALS human tissue, we evaluated expression data from a well-characterized mouse model ${ }^{17}$. The RNA expression data were analyzed in non-transgenic SOD1 WT and SOD1 G93A mice at 75 and 110 days (GEO accession number GSE4390). Differential expression of $U G C G$ was independently replicated in the SOD1 G93A mice (Fig. 6b). Additionally, we found that TBK1 within the purple cluster, NDSTI and WIPI2 within the orange cluster, and KIF5A within the green cluster were enriched in SOD1 G93A mice (Fig. 6b).

\section{Discussion}

We sought to elucidate the genetic basis of sporadic ALS. By exploiting statistical power from several large GWAS of >3 million people, we identified novel susceptibility loci, each associated with a small increase in ALS risk. We found that ALS variants form a small-world coexpression network characterized by highly inter-connected 'hub' genes. This network clustered into smaller sub-networks, each with a unique function. Altered gene expression of several subnetworks and hubs was over-represented in neuropathological samples from ALS patients and SOD1 G93A mice. Our collective findings indicate that the genetic architecture of ALS can be partitioned into distinct components where some genes are highly important for developing disease.

We found that ALS has a robust polygenic component. By leveraging genetic studies from 65 different traits and diseases, we identified 89 ALS risk loci across 21 chromosomes of 
which 59 are novel. Beyond C9ORF72, our pleiotropy analyses detected novel genetic signal within numerous loci including GIPC1, ELMO1 and COL16A and confirmed previously reported variants, such as ATXN2, KIF5A, UNC13A and MOBP ${ }^{4-6}$. Neither as polygenic as schizophrenia $^{18}$ or Alzheimer's disease ${ }^{19}$ nor purely oligogenic ${ }^{5}$, it is likely that the genetic architecture of ALS is a continuum of common low-risk variants and rare high-risk variants. Although each of the ALS susceptibility loci we detected was associated with a small effect, when aggregated together into a polygenic score they may explain a substantial portion of the inherited risk underlying $\mathrm{ALS}^{20}$.

We found genetic pleiotropy between ALS and a number of diseases and traits. In line with previous reports, we show strong genetic enrichment in ALS conditional on FTD and $\mathrm{PSP}^{8,21,22}$. Building on prior work showing a relationship between inflammation/immune dysfunction and motor neuron disease ${ }^{23-25}$, we found enrichment in ALS SNPs as a function of CRP and celiac disease. Surprisingly, we also identified strong genetic overlap between ALS and $\mathrm{CAD}$, and memory function. Clinically, these findings suggest that a subset of ALS patients are at elevated genetic risk for FTD whereas another (potentially overlapping) group of ALS individuals may be at high risk for CAD or immune dysfunction. Therefore, development of multiple pathway specific polygenic scores may identify individuals at risk for developing ALS who are 'enriched' for FTD, cardiovascular or immune mediated processes.

Our findings inform cohort stratification and enrichment strategies for ALS clinical trials. We found that the ALS pleiotropic and functional risk genes form a small-world co-expression network. This network can be partitioned into 8 subnetworks, each enriched for distinct biological pathways. Similar to previous research, we found functional enrichment of ALS risk genes for oxidative-mediated (teal subnetwork), neuronal (teal, blue, yellow, and green 
subnetworks), and endoplasmic reticulum processes (orange subnetwork) ${ }^{26,27}$. Additionally, genes within the blue subnetwork were enriched for developmental and growth pathways while genes within the gray subnetwork were enriched for cell-death and apoptotic processes. Altered gene expression within the teal subnetwork was over-represented in postmortem spinal cord samples from familial and sporadic ALS patients, whereas abnormal expression of genes in the orange and purple clusters was present in SOD1 G93A mice. Clinically, these results suggest that partitioning genetic susceptibility may help identify individuals who have a higher likelihood of responding to therapies with a specific mechanism of action and support including DNA collection and sequencing in ALS clinical trials. For example, ALS patients who are enriched for genetic abnormalities within the teal subnetwork may respond to therapies targeting oxidation reduction or steroid catabolism (Fig. 5). On the other hand, vascular treatments may be effective in ALS individuals with an overabundance of altered purple cluster genes (Fig. 5).

Not all ALS genes are created equal. We show that particular genes within the ALS coexpression network are characteristic of hubs. Playing a central role within a biological system, perturbation of a hub can cause rapid degeneration of the whole network ${ }^{28}$. We found that these hub genes were key drivers of biological enrichment. Specifically, HTR2A, SMARCA2, and GIPC1 were enriched for neuronal processes (Supplementary Fig. 5), and ELMO1 and DOCK2 were enriched for vesicle-mediated transport (Supplementary Fig. 6). Therapeutically targeting hub genes may be most effective for altering an entire biological pathway. However, given abundant pleiotropy with other traits (Supplementary Fig. 2), comprehensive biological and experimental evaluation of the entire network of a hub gene will be necessary prior to therapeutic evaluation. 
This study should be interpreted within the context of its limitations. First, the ALS GWAS used contained people predominantly of European descent, while the other GWAS included people of both European and non-European descent. Therefore, these results may not be generalizable to ALS patients from other populations. Second, like most GWAS, a major limitation of our study is that we could not determine with certainty the causal genes underlying our genetic signal. Although we performed extensive LD and cis-eQTL analyses and included the combination of closest and functional genes in our network analyses, it is likely that genetic fine mapping and experimental approaches, such as CRISPR/Cas9 gene editing, will be needed to isolate the causal variants. Finally, given evidence that a substantial proportion of coronary disease is associated with inflammation ${ }^{29}$, future work should evaluate whether CAD influences ALS risk through inflammation or other mediator variables.

In summary, we show that the genetic architecture of ALS has a robust polygenic component that can be partitioned into distinct subnetworks, each enriched for divergent biological pathways. We also identify several hub genes that may be key drivers of ALS pathobiology. Our findings are compatible with the hypothesis that ALS is a multi-step, nonuniform disease process. These results have implications for cohort stratification and enrichment strategies for ALS clinical trials.

\section{Methods}

\section{Participant samples}

We conducted a meta-analysis of summary data obtained from published data. We evaluated complete GWAS results in the form of summary statistics (p-values and odds ratios) for ALS and 65 distinct traits and diseases (see Supplementary Table 4). We obtained ALS 
GWAS summary statistic data from 12,577 ALS cases and 23,475 controls at 18,741,501 SNPs (see Supplementary Table 4 for additional details). The ALS GWAS summary statistics and sequenced variants are publicly available through the Project MinE data browser:

http://databrowser.projectmine.com. We also obtained GWAS summary statistic data for the 65 distinct traits and diseases (for additional details, please see Supplementary Table 4). The relevant institutional review boards or ethics committees approved the research protocol of the individual GWASs used in the current analysis, and all participants gave written informed consent.

\section{Genetic Enrichment Statistical Analyses}

The pleiotropic enrichment strategies implemented here were derived from previously published stratified FDR methods ${ }^{13,30}$. For given phenotypes A and B, pleiotropic 'enrichment' of phenotype A with phenotype B exists if the proportion of SNPs or genes associated with phenotype A increases as a function of increased association with phenotype B. To assess for enrichment, we constructed fold-enrichment plots of nominal $-\log _{10}(\mathrm{p})$ values for all ALS SNPs and for subsets of SNPs determined by the significance of their association with the 65 distinct traits and diseases. In fold-enrichment plots, the presence of enrichment is reflected as an upward deflection of the curve for phenotype A with increasing strength of association with phenotype B. To assess for polygenic effects below the standard GWAS significance threshold, we focused the fold-enrichment plots on SNPs with nominal $-\log _{10}(\mathrm{p})<7.3$ (corresponding to $\mathrm{p}>5 \times 10^{-8}$ ). The enrichment seen can be directly interpreted in terms of true discovery rate (TDR $=1-$ False Discovery Rate (FDR)). Given prior evidence that several genetic variants within chromosome 9 are associated with increased ALS risk, one concern is that random pruning may not sufficiently 
account for these large LD blocks, resulting in artificially inflated genetic enrichment ${ }^{12}$. To better account for these large LD blocks, in our genetic enrichment analyses, we removed all SNPs within chromosome 9.

To identify novel ALS risk loci as a function of genetic variants associated with the 65 traits and diseases, we computed conditional FDRs ${ }^{13,30}$, a statistical framework that is well suited for gene detection. The standard FDR framework is based on Bayesian statistics and follows the assumption that SNPs are either associated with the phenotype (non-null) or are not associated with the phenotype (null SNPs). Within a Bayesian statistical framework, the FDR is then the posterior probability of the SNP being null given its p-value is as small as or smaller than the observed one. The conditional FDR is an extension of the standard FDR, which incorporates information from GWAS summary statistics of a second phenotype to adjust its significance level. The conditional FDR is defined as the probability that a SNP is null in the first phenotype given that the p-values in the first and second phenotypes are as small as or smaller than the observed ones. Ranking SNPs by the standard FDR or by p-values gives the same ordering of SNPs. In contrast, if the primary and secondary phenotypes are related genetically, the conditional FDR reorders SNPs and results in a different ranking than that based on p-values alone. We used an overall FDR threshold of $\mathrm{p}<.05$ to indicate statistical significance, meaning 5 expected false discoveries per 100 reported. In addition, we constructed Manhattan plots based on the ranking of the conditional FDR to illustrate the genomic location. In all analyses, we controlled for the effects of genomic inflation. Detailed information on the conditional FDR can be found in prior reports ${ }^{13,30}$. 


\section{Functional evaluation of shared risk loci}

To assess whether the SNPs associated with ALS and the 65 traits and diseases modify gene expression, we identified cis-expression quantitative loci (eQTLs, defined as variants within $1 \mathrm{Mb}$ of a gene's transcription start site) associated with the identified ALS pleiotropic SNPs and measured their regional brain expression in a publicly available dataset of normal control brains (UK Brain Expression Consortium, http://braineac.org/) $)^{31}$. To minimize multiple comparisons, we analyzed cis-eQTL for the mean p-value obtained from the following brain regions: the cerebellum, frontal cortex, hippocampus, medulla, occipital cortex, putamen, substantia nigra, temporal cortex, thalamus, and white matter. To minimize false positives, we applied a Bonferroni-corrected p-value of $1.5 \times 10^{-3}$.

\section{Biological networks associated with ALS genetic risk genes}

To evaluate potential protein and genetic interactions, co-expression, co-localization, and protein domain similarity for the combined pleiotropic (i.e. closest genes from the pleiotropy analyses) and functionally expressed ALS genes (i.e., with significant cis-eQTLs), we used GeneMANIA (www.genemania.org), an online web-portal for bioinformatic assessment of gene networks ${ }^{14}$. To visualize the composite gene network, we also assessed the weights of individual components within the network ${ }^{32}$. Further, we evaluated whether the biological networks fell into the class of a small-world network using several diagnostic criteria. First, we computed the “small-worldness" index, using the R package 'qgraph'. The function computes the global transitivity of the target network and its average shortest path length ${ }^{16,33}$. It then computes the same indices on 1000 random networks. The small-worldness index is then equal to the transitivity of the target network (normalized by the random transitivity) over the average 
shortest path of the target network (normalized by the random average shortest path length). A network was considered small-world if the "small-worldness" index was $>=3 ;{ }^{16}$. In addition to the small-worldness index, we inspected whether the network had a transitivity substantially higher than comparable random networks and that its average shortest path length was similar or higher (but not substantially higher) than that computed on random networks.

Further, to determine whether some genes play a more influential role than others, we evaluated various network centrality measures, including degree centrality, eigenvector centrality, and edge-betweenness centrality. We used the R package 'igraph' for all network centrality analysis and visualization ${ }^{34}$. The degree of a node corresponds to the sum of its adjacent edges (i.e., connections). The eigenvector centrality of a node corresponds to the values of the first eigenvector of the graph adjacency matrix. In general, nodes with high eigenvector centralities are also connected to many other nodes which are, in turn, connected to many other nodes. Consequently, eigenvector centrality corresponds to the degree to which a node is connected to other highly influential nodes. Lastly, we partitioned the co-expression network, in particular, into subnetworks based on edge-betweenness centrality. Edge-betweenness centrality is defined by the number of shortest-paths going through an edge. Here, a subnetwork is analogous to modules within a network. Nodes within a module are densely connected to themselves (e.g., cluster) but sparsely connected to other modules. To create modules, we gradually remove the edge with the highest edge-betweenness score, since all the shortest paths from one module to another typically pass through them. The result is a hierarchical map, called a dendrogram. The leaves of the tree are the individual nodes and the root of the tree represents the whole graph. 
Lastly, to evaluate biological pathways of the ALS pleiotropic genes (i.e. closest genes from the pleiotropy analyses) and functionally expressed ALS genes (i.e., with significant ciseQTLs), we used FUMA (http://fuma.ctglab.nl/), a web-based platform that integrates information from multiple biological resources to facilitate functional annotation of GWAS results ${ }^{35}$.

\section{Gene expression alterations in tissue from ALS patients and SOD1 G93A transgenic mice}

To determine whether the ALS genetic risk genes were differentially expressed in tissue from patients with ALS, we analyzed the gene expression of the target genes from postmortem spinal cord gray matter from 11 individuals (2 patients with familial ALS, 5 patients with sporadic ALS, and 4 controls; Gene Expression Omnibus [GEO] accession number GDS412 ${ }^{36}$ ). Details about this dataset and analysis-including the human brain samples used, RNA extraction and hybridization methods, microarray quality control, and microarray data analysis- are described in the original manuscript ${ }^{36}$. To validate the genes identified in ALS human tissue, we also analyzed RNA expression data in non-transgenic SOD1 WT (n=2) and SOD1 G93A (n=2) mice at 75 and 110 days (GEO accession number GSE4390). SOD1 G93A mice are presymptomatic at 75 days and exhibit hindlimb paralysis at 110 days ${ }^{17,37}$.

\section{Code availability}

Code and scripts available by request from authors.

\section{Data availability}


Summary statistics from secondary GWAS of single disorders and traits are available upon request from the corresponding author. Cis-eqtl data from the UK Brain Expression Consortium are publicly available (http://braineac.org/). Findings from biological networks were obtained using GeneMANIA (www.genemania.org), an online web-portal for bioinformatic assessment of gene networks. Biological pathways were evaluated using FUMA (http://fuma.ctglab.nl/), a webbased platform that integrates information from multiple biological resources to facilitate functional annotation of GWAS results. Expression data from sporadic and familial ALS patients and controls postmortem spinal cord gray matter are available in GEO with the accession number GDS412. RNA expression data in non-transgenic SOD1 WT and SOD1 G93A mice at 75 and 110 days are also available in GEO with the accession number GSE4390. 


\section{ACKNOWLEDGEMENTS}

We salute the millions of people who battle with ALS every single day - your courage is our strength. This research is in part an EU Joint Programme - Neurodegenerative Disease Research (JPND) project. The project is supported through the following funding organizations under the aegis of NL (ZONMW) and JPND - www.jpnd.eu (United Kingdom, Medical Research Council (MR/L501529/1 (STRENGTH); MR/R024804/1 (BRAIN-MEND)) and Economic and Social Research Council ((ES/L008238/1) ALS-CarE) and through the Motor Neurone Disease Association. This study represents independent research part funded by the National Institute for Health Research (NIHR) Biomedical Research Centre at South London and Maudsley NHS Foundation Trust and King's College London. This project has also received funding from the European Research Council (ERC) under the European Union's Horizon 2020 research and innovation programme (grant agreement $n^{\circ} 772376$ - EScORIAL). 


\section{References}

1. Brown RH, Al-Chalabi A. Amyotrophic lateral sclerosis. N Engl J Med 377, 162-72 (2017).

2. van Blitterswijk M, van Es MA, Hennekam EA, Dooijes D, van Rheenen W, Medic J, et al.

Evidence for an oligogenic basis of amyotrophic lateral sclerosis. Hum Mol Genet, Sep 1;21(17):3776-84.

3. Bury JJ, Highley JR, Cooper-Knock J, Goodall EF, Higginbottom A, McDermott CJ, et al. Oligogenic inheritance of optineurin (OPTN) and C9ORF72 mutations in ALS highlights localisation of OPTN in the tdp-43-negative inclusions of C9ORF72-ALS. Neuropathology 2016, Apr;36(2):125-34.

4. Al-Chalabi A, van den Berg LH, Veldink J. Gene discovery in amyotrophic lateral sclerosis: Implications for clinical management. Nat Rev Neurol 2017, Feb;13(2):96-104.

5. van Rheenen W, Shatunov A, Dekker AM, McLaughlin RL, Diekstra FP, Pulit SL, et al. Genome-wide association analyses identify new risk variants and the genetic architecture of amyotrophic lateral sclerosis. Nat Genet 2016;48(9):1043-8.

6. Elden AC, Kim HJ, Hart MP, Chen-Plotkin AS, Johnson BS, Fang X, et al. Ataxin-2 intermediate-length polyglutamine expansions are associated with increased risk for ALS. Nature 2010, Aug 26;466(7310):1069-75.

7. McLaughlin RL, Schijven D, van Rheenen W, van Eijk KR, O'Brien M, Kahn RS, et al. Genetic correlation between amyotrophic lateral sclerosis and schizophrenia. Nat Commun 2017, $\operatorname{Mar} 21 ; 8: 14774$.

8. Karch CM, Wen N, Fan CC, Yokoyama JS, Kouri N, Ross OA, et al. Selective genetic overlap between amyotrophic lateral sclerosis and diseases of the frontotemporal dementia spectrum. JAMA Neurol 2018, Apr 9. 
9. Desikan RS, Schork AJ, Wang Y, Thompson WK, Dehghan A, Ridker PM, et al. Polygenic overlap between c-reactive protein, plasma lipids, and alzheimer disease. Circulation 2015, Jun 9;131(23):2061-9.

10. Yokoyama JS, Karch CM, Fan CC, Bonham LW, Kouri N, Ross OA, et al. Shared genetic risk between corticobasal degeneration, progressive supranuclear palsy, and frontotemporal dementia. Acta Neuropathol 2017, May;133(5):825-37.

11. Ferrari R, Wang Y, Vandrovcova J, Guelfi S, Witeolar A, Karch CM, et al. Genetic architecture of sporadic frontotemporal dementia and overlap with alzheimer's and parkinson's diseases. J Neurol Neurosurg Psychiatry 2017;88(2):152-64.

12. Broce I, Karch CM, Wen N, Fan CC, Wang Y, Tan CH, et al. Correction: Immune-related genetic enrichment in frontotemporal dementia: An analysis of genome-wide association studies. PLoS Med 2018, Jan;15(1):e1002504.

13. Andreassen OA, Djurovic S, Thompson WK, Schork AJ, Kendler KS, O'Donovan MC, et al. Improved detection of common variants associated with schizophrenia by leveraging pleiotropy with cardiovascular-disease risk factors. Am J Hum Genet 2013, Feb 7;92(2):197-209.

14. David Warde-Farley. The genemania prediction server: Biological network integration for gene prioritization and predicting gene function. Nucleic Acids Res 2010, Jul 1;38(Web Server issue):W214.

15. Watts DJ, Strogatz SH. Collective dynamics of 'small-world' networks. Nature 1998, Jun $4 ; 393(6684): 440-2$.

16. Humphries MD, Gurney K. Network 'small-world-ness': A quantitative method for determining canonical network equivalence. PLoS One 2008, Apr 30;3(4):e0002051. 
17. Karch CM, Prudencio M, Winkler DD, Hart PJ, Borchelt DR. Role of mutant SOD1 disulfide oxidation and aggregation in the pathogenesis of familial ALS. Proc Natl Acad Sci U S A 2009, May 12;106(19):7774-9.

18. Schork AJ, Wang Y, Thompson WK, Dale AM, Andreassen OA. New statistical approaches exploit the polygenic architecture of schizophrenia--implications for the underlying neurobiology. Curr Opin Neurobiol 2016, Feb;36:89-98.

19. Escott-Price V, Sims R, Bannister C, Harold D, Vronskaya M, Majounie E, et al. Common polygenic variation enhances risk prediction for alzheimer's disease. Brain 2015, Dec;138(Pt 12):3673-84.

20. Torkamani A, Wineinger NE, Topol EJ. The personal and clinical utility of polygenic risk scores. Nat Rev Genet 2018, Sep;19(9):581-90.

21. Wilke C, Baets J, De Bleecker JL, Deconinck T, Biskup S, Hayer SN, et al. Beyond ALS and FTD: The phenotypic spectrum of TBK1 mutations includes psp-like and cerebellar phenotypes. Neurobiol Aging 2018;62:244.e9-244.e13.

22. Chen JA, Chen Z, Won H, Huang AY, Lowe JK, Wojta K, et al. Joint genome-wide association study of progressive supranuclear palsy identifies novel susceptibility loci and genetic correlation to neurodegenerative diseases. Mol Neurodegener 2018;13(1):41.

23. Ryberg H, An J, Darko S, Lustgarten JL, Jaffa M, Gopalakrishnan V, et al. Discovery and verification of amyotrophic lateral sclerosis biomarkers by proteomics. Muscle Nerve 2010, Jul;42(1):104-11.

24. Turner MR, Goldacre R, Ramagopalan S, Talbot K, Goldacre MJ. Autoimmune disease preceding amyotrophic lateral sclerosis: An epidemiologic study. Neurology 2013, Oct $1 ; 81(14): 1222-5$. 
25. Hemminki K, Li X, Sundquist J, Sundquist K. Familial risks for amyotrophic lateral sclerosis and autoimmune diseases. Neurogenetics 2009, Apr;10(2):111-6.

26. Zou ZY, Liu CY, Che CH, Huang HP. Toward precision medicine in amyotrophic lateral sclerosis. Ann Transl Med 2016, Jan;4(2):27.

27. Ferraiuolo L, Kirby J, Grierson AJ, Sendtner M, Shaw PJ. Molecular pathways of motor neuron injury in amyotrophic lateral sclerosis. Nat Rev Neurol 2011, Nov;7(11):616.

28. Hopkins AL. Network pharmacology: The next paradigm in drug discovery. Nat Chem Biol 2008, Nov;4(11):682-90.

29. Harrington RA. Targeting inflammation in coronary artery disease. $N$ Engl J Med 2017;377(12):1197-8.

30. Andreassen OA, Thompson WK, Schork AJ, Ripke S, Mattingsdal M, Kelsoe JR, et al. Improved detection of common variants associated with schizophrenia and bipolar disorder using pleiotropy-informed conditional false discovery rate. PLoS Genet 2013, Apr;9(4):e1003455.

31. Ramasamy A, Trabzuni D, Guelfi S, Varghese V, Smith C, Walker R, et al. Genetic variability in the regulation of gene expression in ten regions of the human brain. Nat Neurosci 2014, Oct;17(10):1418-28.

32. Mostafavi S, Ray D, Warde-Farley D, Grouios C, Morris Q. GeneMANIA: A real-time multiple association network integration algorithm for predicting gene function. Genome Biol 2008;9 Suppl 1:S4.

33. Newman E J. The structure and function of complex networks. SIAM Review 2003;45(3):167-256.

34. Kolaczyk ED, Csárdi G. Statistical analysis of network data with R. New York, N.Y: Springer; 2014. 
35. Kyoko Watanabe. Functional mapping and annotation of genetic associations with FUMA. Nat Commun 2017;8.

36. Dangond F, Hwang D, Camelo S, Pasinelli P, Frosch MP, Stephanopoulos G, et al.

Molecular signature of late-stage human ALS revealed by expression profiling of postmortem spinal cord gray matter. Physiol Genomics 2004, Jan 15;16(2):229-39.

37. Lukas TJ, Luo WW, Mao H, Cole N, Siddique T. Informatics-assisted protein profiling in a transgenic mouse model of amyotrophic lateral sclerosis. Mol Cell Proteomics 2006, $\mathrm{Jul} ; 5(7): 1233-44$.

38. Daoud H, Valdmanis PN, Gros-Louis F, Belzil V, Spiegelman D, Henrion E, et al. Resequencing of 29 candidate genes in patients with familial and sporadic amyotrophic lateral sclerosis. Arch Neurol 2011, May;68(5):587-93.

39. Kwee LC, Liu Y, Haynes C, Gibson JR, Stone A, Schichman SA, et al. A high-density genome-wide association screen of sporadic ALS in US veterans. PLoS One 2012;7(3):e32768. 40. Benyamin B, He J, Zhao Q, Gratten J, Garton F, Leo PJ, et al. Cross-ethnic meta-analysis identifies association of the GPX3-TNIP1 locus with amyotrophic lateral sclerosis. Nat Commun 2017;8(1):611.

41. Haider SA, Faisal M. Human aging in the post-gwas era: Further insights reveal potential regulatory variants. Biogerontology 2015, Aug;16(4):529-41.

42. Kwee LC, Liu Y, Haynes C, Gibson JR, Stone A, Schichman SA, et al. A high-density genome-wide association screen of sporadic ALS in US veterans. PLoS One 2012;7(3):e32768. 43. Chen Y, Zhou Q, Gu X, Wei Q, Cao B, Liu H, et al. An association study between SCFD1 rs 10139154 variant and amyotrophic lateral sclerosis in a chinese cohort. Amyotroph Lateral Scler Frontotemporal Degener 2018, Aug;19(5-6):413-8. 
44. Simpson CL, Lemmens R, Miskiewicz K, Broom WJ, Hansen VK, van Vught PW, et al. Variants of the elongator protein 3 (ELP3) gene are associated with motor neuron degeneration. Hum Mol Genet 2009, Feb 1;18(3):472-81.

45. Morahan JM, Yu B, Trent RJ, Pamphlett R. A genome-wide analysis of brain DNA methylation identifies new candidate genes for sporadic amyotrophic lateral sclerosis. Amyotroph Lateral Scler 2009;10(5-6):418-29.

46. Gijselinck I, Van Langenhove T, van der Zee J, Sleegers K, Philtjens S, Kleinberger G, et al. A c9orf72 promoter repeat expansion in a flanders-belgian cohort with disorders of the frontotemporal lobar degeneration-amyotrophic lateral sclerosis spectrum: A gene identification study. Lancet Neurol 2012, Jan;11(1):54-65.

47. Schymick JC, Scholz SW, Fung HC, Britton A, Arepalli S, Gibbs JR, et al. Genome-wide genotyping in amyotrophic lateral sclerosis and neurologically normal controls: First stage analysis and public release of data. Lancet Neurol 2007, Apr;6(4):322-8.

48. Fogh I, Ratti A, Gellera C, Lin K, Tiloca C, Moskvina V, et al. A genome-wide association meta-analysis identifies a novel locus at 17q11.2 associated with sporadic amyotrophic lateral sclerosis. Hum Mol Genet 2014, Apr;23(8):2220-31.

49. Lahut S, Ömür Ö, Uyan Ö, Ağım ZS, Özoğuz A, Parman Y, et al. ATXN2 and its neighbouring gene $\mathrm{SH} 2 \mathrm{~B} 3$ are associated with increased ALS risk in the turkish population. PLoS One 2012;7(8):e42956.

50. Cirulli ET, Lasseigne BN, Petrovski S, Sapp PC, Dion PA, Leblond CS, et al. Exome sequencing in amyotrophic lateral sclerosis identifies risk genes and pathways. Science 2015, Mar 27;347(6229):1436-41. 
51. van Doormaal PTC, Ticozzi N, Weishaupt JH, Kenna K, Diekstra FP, Verde F, et al. The role of de novo mutations in the development of amyotrophic lateral sclerosis. Hum Mutat 2017;38(11):1534-41.

52. Freischmidt A, Wieland T, Richter B, Ruf W, Schaeffer V, Müller K, et al. Haploinsufficiency of TBK1 causes familial ALS and fronto-temporal dementia. Nat Neurosci 2015, May;18(5):631-6.

53. Nicolas A, Kenna KP, Renton AE, Ticozzi N, Faghri F, Chia R, et al. Genome-wide analyses identify KIF5A as a novel ALS gene. Neuron 2018, Mar 21;97(6):1268-1283.e6.

54. Saba R, Medina SJ, Booth SA. A functional SNP catalog of overlapping mirna-binding sites in genes implicated in prion disease and other neurodegenerative disorders. Hum Mutat 2014, Oct;35(10):1233-48.

55. Cronin S, Berger S, Ding J, Schymick JC, Washecka N, Hernandez DG, et al. A genomewide association study of sporadic ALS in a homogenous irish population. Hum Mol Genet 2008, Mar;17(5):768-74.

56. Orozco D, Edbauer D. FUS-mediated alternative splicing in the nervous system:

Consequences for ALS and FTLD. J Mol Med 2013, Dec;91(12):1343-54.

57. Lambert JC, Ibrahim-Verbaas CA, Harold D, Naj AC, Sims R, Bellenguez C, et al. Metaanalysis of 74,046 individuals identifies 11 new susceptibility loci for Alzheimer's disease. Nat Genet 2013, Dec;45(12):1452-8.

58. Demontis D, Walters RK, Martin J, Mattheisen M, Als TD, Agerbo E, et al. Discovery of the first genome-wide significant risk loci for ADHD. BioRxiv 2017, Jun:145581. 
59. Lo M-T, Hinds DA, Tung JY, Franz C, Fan C-C, Wang Y, et al. Genome-wide analyses for personality traits identify six genomic loci and show correlations with psychiatric disorders. Nat Genet 2016, Dec;49(1):152.

60. Clarke TK, Adams MJ, Davies G, Howard DM, Hall LS, Padmanabhan S, et al. Genomewide association study of alcohol consumption and genetic overlap with other health-related traits in UK biobank (N=112 117). Mol Psychiatry 2017, Oct;22(10):1376-84.

61. Tielbeek JJ, Johansson A, Polderman TJC, Rautiainen MR, Jansen P, Taylor M, et al. Genome-Wide association studies of a broad spectrum of antisocial behavior. JAMA Psychiatry 2017, Dec 1;74(12):1242-50.

62. Consortium TASDWGOTPG. Meta-analysis of GWAS of over 16,000 individuals with autism spectrum disorder highlights a novel locus at 10q24.32 and a significant overlap with schizophrenia. Molecular Autism 2017, May;8(1):21.

63. Stahl E, Forstner A, McQuillin A, Ripke S, PGC BDWGOT, Ophoff R, et al. Genomewide association study identifies 30 loci associated with bipolar disorder. BioRxiv 2017, Aug:173062. 64. Locke AE, Kahali B, Berndt SI, Justice AE, Pers TH, Day FR, et al. Genetic studies of body mass index yield new insights for obesity biology. Nature 2015, Feb 12;518(7538):197-206. 65. Witt SH, Streit F, Jungkunz M, Frank J, Awasthi S, Reinbold CS, et al. Genome-wide association study of borderline personality disorder reveals genetic overlap with bipolar disorder, major depression and schizophrenia. Transl Psychiatry 2017;7(6):e1155.

66. Michailidou K, Hall P, Gonzalez-Neira A, Ghoussaini M, Dennis J, Milne RL, et al. Largescale genotyping identifies 41 new loci associated with breast cancer risk. Nat Genet 2013, Mar;45(4):353. 
67. Consortium TC, Nikpay M, Goel A, Won H-H, Hall LM, Willenborg C, et al. A

comprehensive 1000 genomes-based genome-wide association meta-analysis of coronary artery disease. Nat Genet 2015, Sep;47(10):1121.

68. Kouri N, Ross OA, Dombroski B, Younkin CS, Serie DJ, Soto-Ortolaza A, et al. Genomewide association study of corticobasal degeneration identifies risk variants shared with progressive supranuclear palsy. Nat Commun 2015, Jun 16;6:7247.

69. de Lange KM, Moutsianas L, Lee JC, Lamb CA, Luo Y, Kennedy NA, et al. Genome-wide association study implicates immune activation of multiple integrin genes in inflammatory bowel disease. Nat Genet 2017, Feb;49(2):256-61.

70. Dubois PC, Trynka G, Franke L, Hunt KA, Romanos J, Curtotti A, et al. Multiple common variants for celiac disease influencing immune gene expression. Nat Genet 2010, Apr;42(4):295302.

71. Jones SE, Tyrrell J, Wood AR, Beaumont RN, Ruth KS, Tuke MA, et al. Genome-Wide association analyses in 128,266 individuals identifies new morningness and sleep duration loci. PLoS Genet 2016, Aug;12(8):e1006125.

72. Tobacco T, Consortium G, Furberg H, Kim Y, Dackor J, Boerwinkle E, et al. Genome-wide meta-analyses identify multiple loci associated with smoking behavior. Nat Genet 2010, Apr;42(5):441.

73. Trampush JW, Yang MLZ, Yu J, Knowles E, Davies G, Liewald DC, et al. GWAS metaanalysis reveals novel loci and genetic correlates for general cognitive function: A report from the COGENT consortium. Mol Psychiatry 2017, Jan;22(3):336. 
74. Davies G, Marioni RE, Liewald DC, Hill WD, Hagenaars SP, Harris SE, et al. Genome-wide association study of cognitive functions and educational attainment in UK biobank (N=112 151). Mol Psychiatry 2016;21(6):758-67.

75. Schumacher FR, Schmit SL, Jiao S, Edlund CK, Wang H, Zhang B, et al. Corrigendum: Genome-wide association study of colorectal cancer identifies six new susceptibility loci. Nat Commun 2015, Oct;6:8739.

76. Dehghan A, Dupuis J, Barbalic M, Bis JC, Eiriksdottir G, Lu C, et al. Meta-analysis of genome-wide association studies in >80 000 subjects identifies multiple loci for c-reactive protein levels. Circulation 2011, Feb 22;123(7):731-8.

77. Studies TICFBPG-WA, Ehret GB, Munroe PB, Rice KM, Bochud M, Johnson AD, et al. Genetic variants in novel pathways influence blood pressure and cardiovascular disease risk. Nature 2011, Sep;478(7367):103.

78. Okbay A, Baselmans BML, Neve J-ED, Turley P, Nivard MG, Fontana MA, et al. Genetic variants associated with subjective well-being, depressive symptoms, and neuroticism identified through genome-wide analyses. Nat Genet 2016, Apr;48(6):624.

79. Okbay A, Beauchamp JP, Fontana MA, Lee JJ, Pers TH, Rietveld CA, et al. Genome-wide association study identifies 74 loci associated with educational attainment. Nature 2016, May;533(7604):539.

80. Ferrari R, Hernandez DG, Nalls MA, Rohrer JD, Ramasamy A, Kwok JB, et al. Frontotemporal dementia and its subtypes: A genome-wide association study. Lancet Neurol 2014, Jul;13(7):686-99. 
81. Savage JE, Jansen PR, Stringer S, Watanabe K, Bryois J, de Leeuw CA, et al. Genome-wide association meta-analysis in 269,867 individuals identifies new genetic and functional links to intelligence. Nat Genet 2018, Jun;50(7):912.

82. Consortium GLG, Willer CJ, Schmidt EM, Sengupta S, Peloso GM, Gustafsson S, et al. Discovery and refinement of loci associated with lipid levels. Nat Genet 2013, Oct;45(11):1274. 83. Wood AR, Esko T, Yang J, Vedantam S, Pers TH, Gustafsson S, et al. Defining the role of common variation in the genomic and biological architecture of adult human height. Nat Genet 2014, Oct;46(11):1173.

84. Hibar DP, Stein JL, Renteria ME, Arias-Vasquez A, Desrivières S, Jahanshad N, et al. Common genetic variants influence human subcortical brain structures. Nature 2015, Jan;520(7546):224.

85. Hammerschlag AR, Stringer S, de Leeuw CA, Sniekers S, Taskesen E, Watanabe K, et al. Genome-wide association analysis of insomnia complaints identifies risk genes and genetic overlap with psychiatric and metabolic traits. Nat Genet 2017, Jun;49(11):1584.

86. Sniekers S, Stringer S, Watanabe K, Jansen PR, Coleman JRI, Krapohl E, et al. Genomewide association meta-analysis of 78,308 individuals identifies new loci and genes influencing human intelligence. Nat Genet 2017, May;49(7):1107.

87. Timofeeva MN, Hung RJ, Rafnar T, Christiani DC, Field JK, Bickeböller H, et al. Influence of common genetic variation on lung cancer risk: Meta-analysis of 14900 cases and 29485 controls. Hum Mol Genet 2012, Nov 15;21(22):4980-95.

88. Wray NR, Ripke S, Mattheisen M, Trzaskowski M, Byrne EM, Abdellaoui A, et al. Genomewide association analyses identify 44 risk variants and refine the genetic architecture of major depression. Nat Genet 2018, May;50(5):668-81. 
89. Day FR, Thompson DJ, Helgason H, Chasman DI, Finucane H, Sulem P, et al. Genomic analyses identify hundreds of variants associated with age at menarche and support a role for puberty timing in cancer risk. Nat Genet 2017, Apr;49(6):834.

90. Day FR, Ruth KS, Thompson DJ, Lunetta KL, Pervjakova N, Chasman DI, et al. Large-scale genomic analyses link reproductive aging to hypothalamic signaling, breast cancer susceptibility and brca1-mediated DNA repair. Nat Genet 2015, Sep;47(11):1294.

91. Sawcer S, Hellenthal G, Pirinen M, Spencer CC, Patsopoulos NA, Moutsianas L, et al. Genetic risk and a primary role for cell-mediated immune mechanisms in multiple sclerosis. Nature 2011, Aug 10;476(7359):214-9.

92. Nalls MA, Plagnol V, Hernandez DG, Sharma M, Sheerin UM, Saad M, et al. Imputation of sequence variants for identification of genetic risks for parkinson's disease: A meta-analysis of genome-wide association studies. Lancet 2011, Feb 19;377(9766):641-9.

93. Eeles RA, Olama AAA, Benlloch S, Saunders EJ, Leongamornlert DA, Tymrakiewicz M, et al. Identification of 23 new prostate cancer susceptibility loci using the icogs custom genotyping array. Nat Genet 2013, Mar;45(4):385.

94. Ellinghaus D, Ellinghaus E, Nair RP, Stuart PE, Esko T, Metspalu A, et al. Combined analysis of genome-wide association studies for crohn disease and psoriasis identifies seven shared susceptibility loci. Am J Hum Genet 2012, Apr 6;90(4):636-47.

95. Höglinger GU, Melhem NM, Dickson DW, Sleiman PM, Wang LS, Klei L, et al. Identification of common variants influencing risk of the tauopathy progressive supranuclear palsy. Nat Genet 2011, Jun 19;43(7):699-705.

96. Okada Y, Wu D, Trynka G, Raj T, Terao C, Ikari K, et al. Genetics of rheumatoid arthritis contributes to biology and drug discovery. Nature 2014, Feb 20;506(7488):376-81. 
97. Schizophrenia Working Group of the Psychiatric Genomics Consortium. Biological insights from 108 schizophrenia-associated genetic loci. Nature 2014, Jul 24;511(7510):421-7.

98. Fuchsberger C, Flannick J, Teslovich TM, Mahajan A, Agarwala V, Gaulton KJ, et al. The genetic architecture of type 2 diabetes. Nature 2016, Jul;536(7614):41.

99. Jin Y, Andersen G, Yorgov D, Ferrara TM, Ben S, Brownson KM, et al. Genome-wide association studies of autoimmune vitiligo identify 23 new risk loci and highlight key pathways and regulatory variants. Nat Genet 2016;48(11):1418-24.

100. Shungin D, Winkler TW, Croteau-Chonka DC, Ferreira T, Locke AE, Mägi R, et al. New genetic loci link adipose and insulin biology to body fat distribution. Nature 2015, Feb $12 ; 518(7538): 187-96$. 


\section{Figures}

\section{Fig. 1: Fold enrichment plots of enrichment versus nominal - $\log 10$ p-values (corrected for}

inflation) in Amyotrophic lateral sclerosis (ALS). Fold enrichment plots of enrichment versus nominal $-\log _{10} \mathrm{p}$-values (corrected for inflation) in ALS below the standard GWAS threshold of p-value $<5 \times 10^{-8}$ as a function of significance of association with 65 distinct traits and diseases and at the level of $p$-value $\leq 1, p$-value $\leq 0.1, p$-value $\leq 0.01$, respectively. Blue line indicates all SNPs.

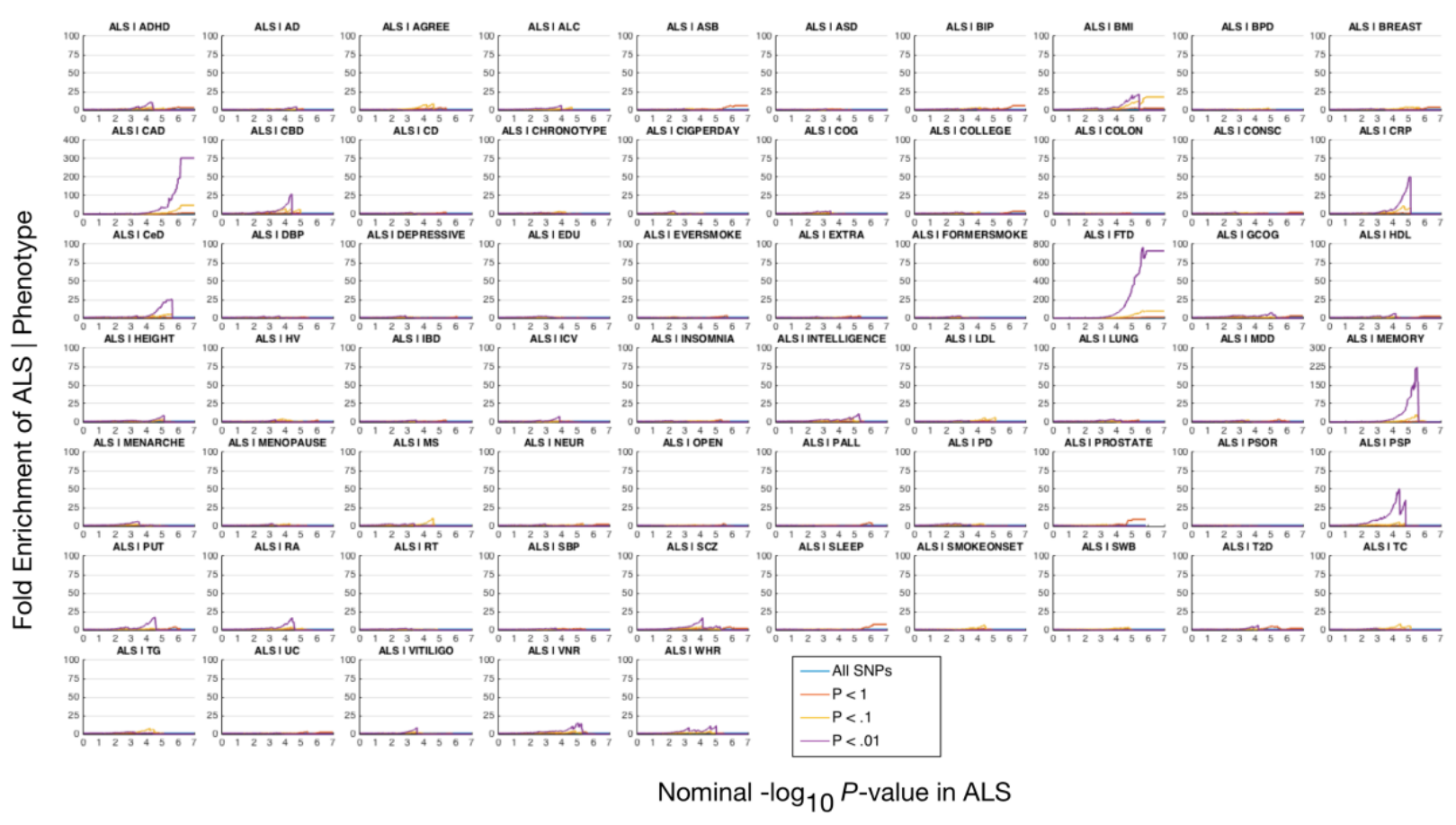


bioRxiv preprint doi: https://doi.org/10.1101/505693; this version posted February 24, 2019. The copyright holder for this preprint (which was not certified by peer review) is the author/funder, who has granted bioRxiv a license to display the preprint in perpetuity. It is made available under aCC-BY-NC-ND 4.0 International license.

Fig. 2: 'Conditional' Manhattan plot of conditional - $\log 10$ (FDR) values for Amyotrophic lateral sclerosis (ALS) as a function of 65 distinct traits and diseases. SNPs with conditional $-\log _{10}$ FDR > 1.3 (i.e. FDR < 0.05) are shown with large points. A black line around the large points indicates the most significant SNP in each LD block and this SNP was annotated with the closest gene, which is listed above the symbols in each locus.

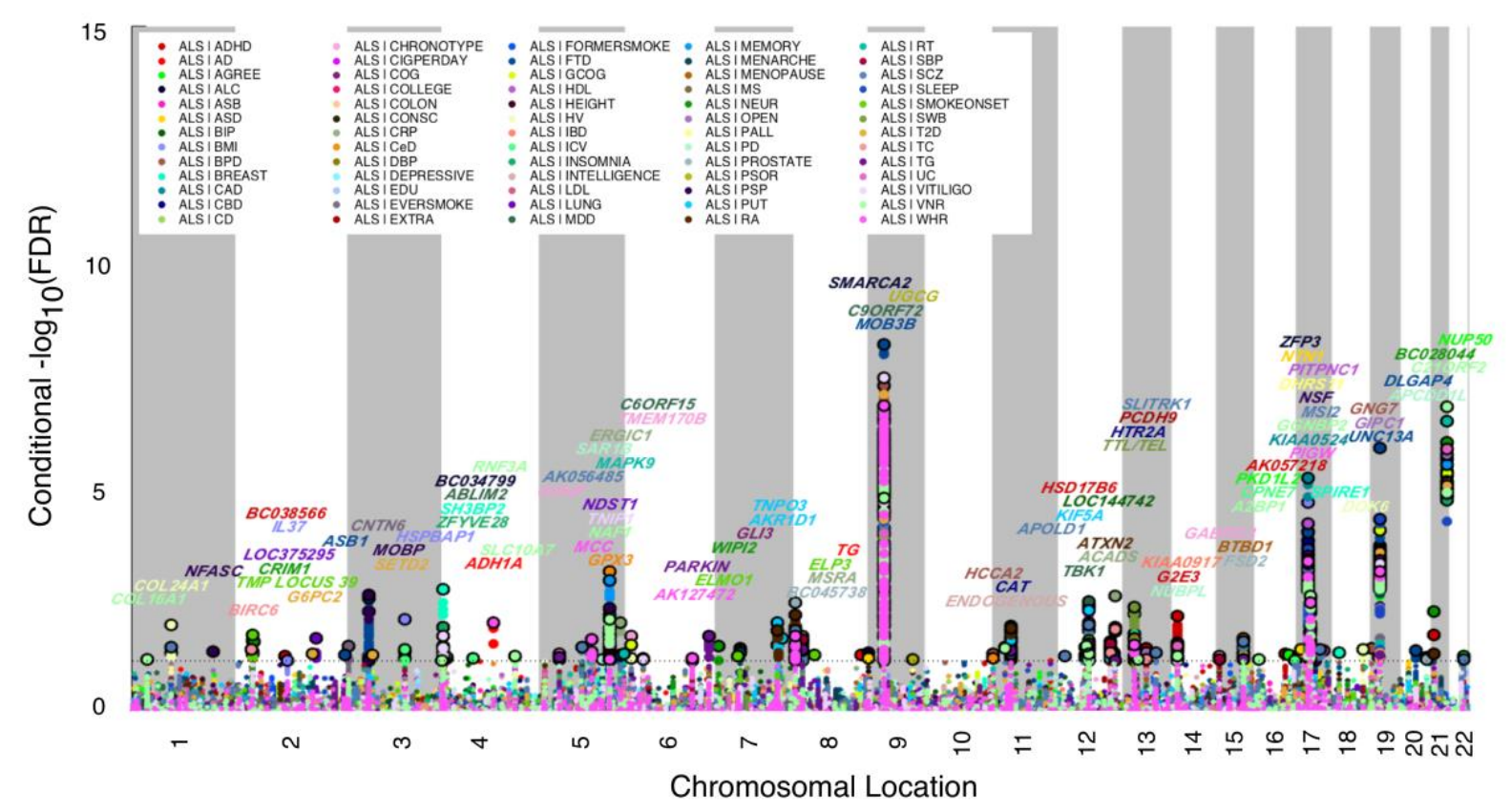


bioRxiv preprint doi: https://doi.org/10.1101/505693; this version posted February 24, 2019. The copyright holder for this preprint (which was not certified by peer review) is the author/funder, who has granted bioRxiv a license to display the preprint in perpetuity. It is made available under aCC-BY-NC-ND 4.0 International license.

Fig. 3: Network interaction graph illustrating genetic interactions, physical interactions, and co-expression patterns associated with the ALS risk genes.

Genetic Interactions (13.28\%)

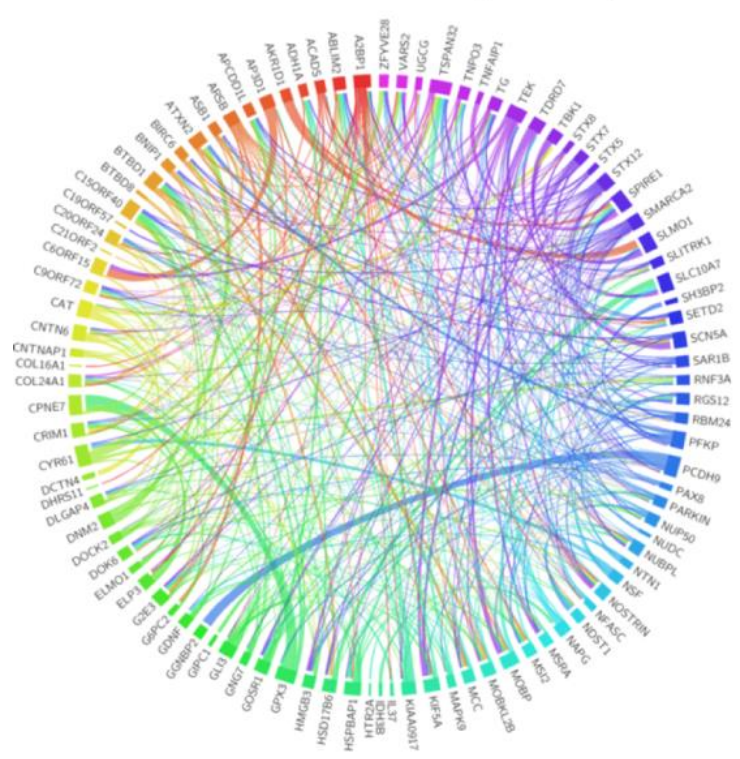

Physical Interactions (42.93\%)

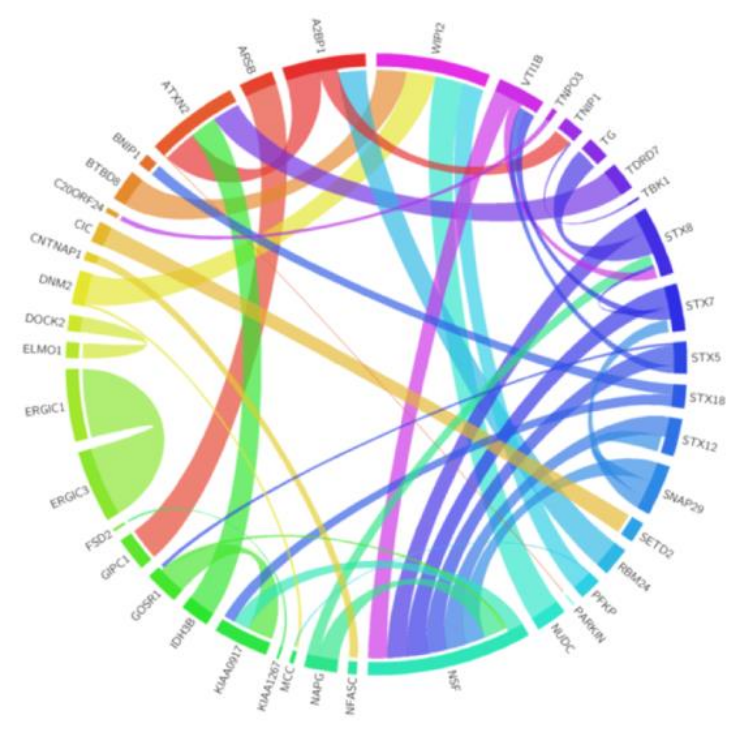

Co-expression (29.33\%)

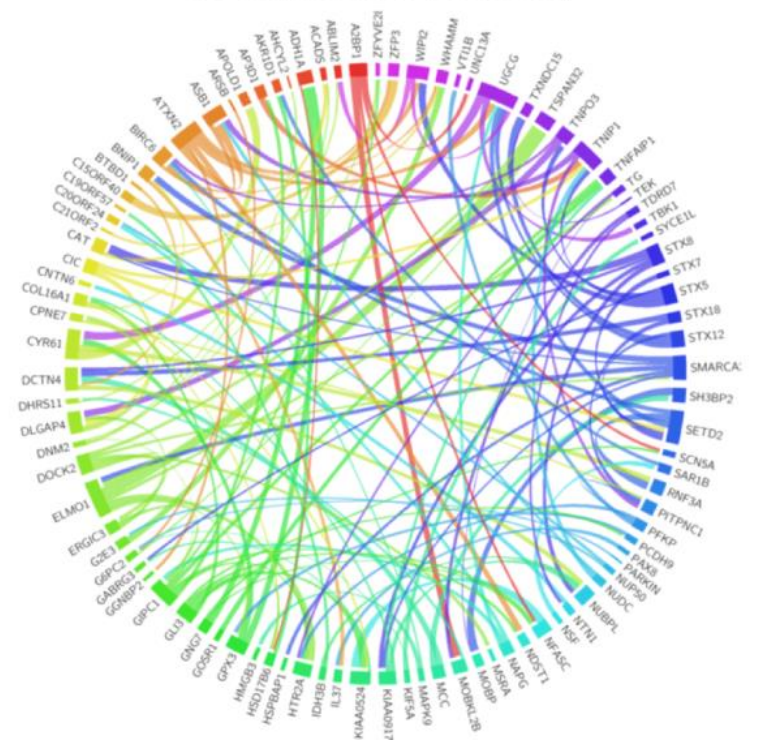


Fig. 4: Co-expression interaction network plot and dendrogram. a, Co-expression interaction network plot. Each node represents a single gene and the edges (lines between genes) represent co-expression interactions between genes. The size of each node corresponds to the eigenvector centrality score for that gene. The color of each node represents membership to a distinct subnetwork. b, Co-expression interaction dendrogram plot. The co-expression network was partitioned into 8 subnetworks by removing edges with high edge-betweenness centrality. Hub genes are annotated in brown and marked by a large point.

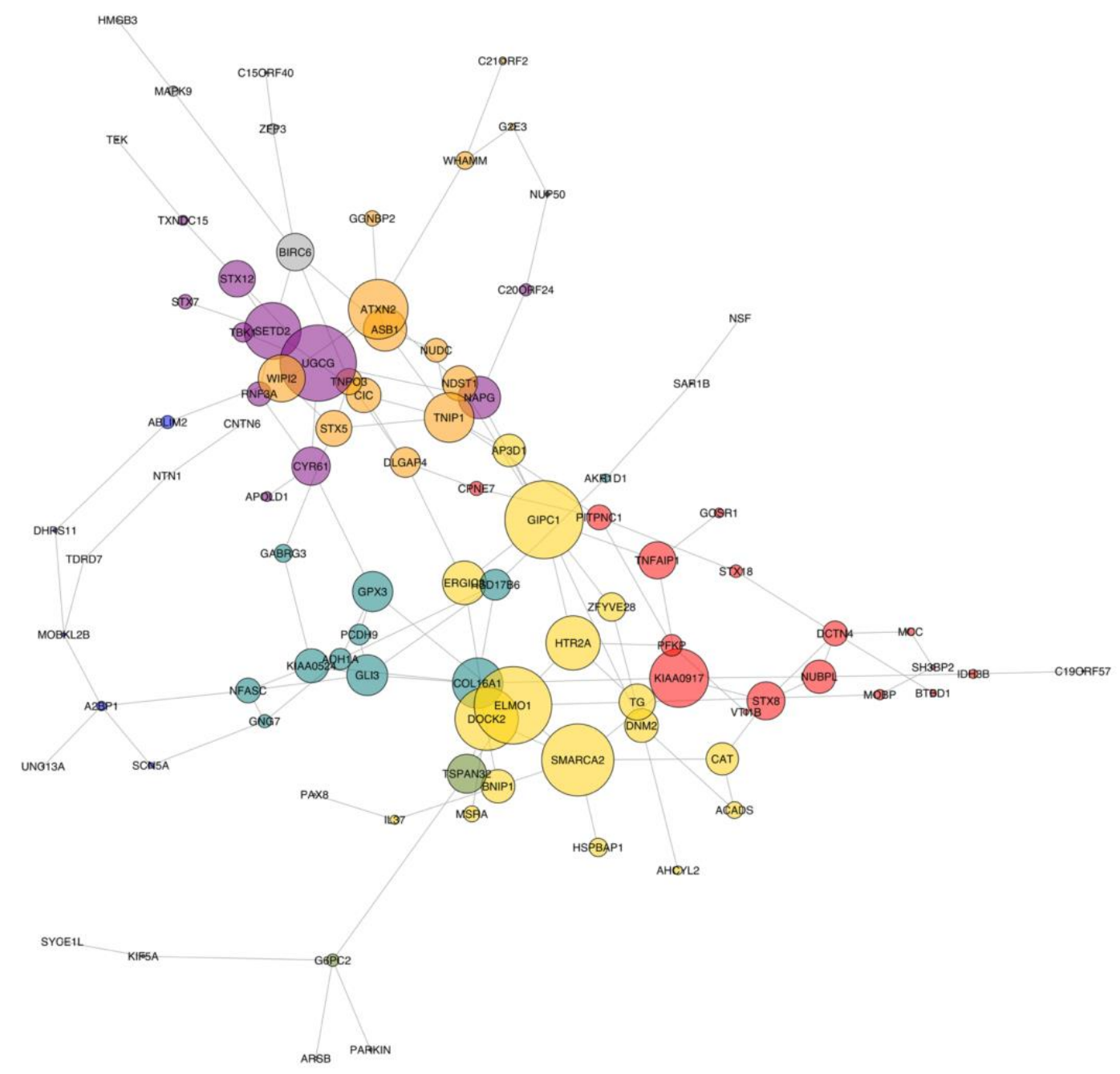


bioRxiv preprint doi: https://doi.org/10.1101/505693; this version posted February 24,2019 . The copyright holder for this preprint (which was not certified by peer review) is the author/funder, who has granted bioRxiv a license to display the preprint in perpetuity. It is made available under aCC-BY-NC-ND 4.0 International license.

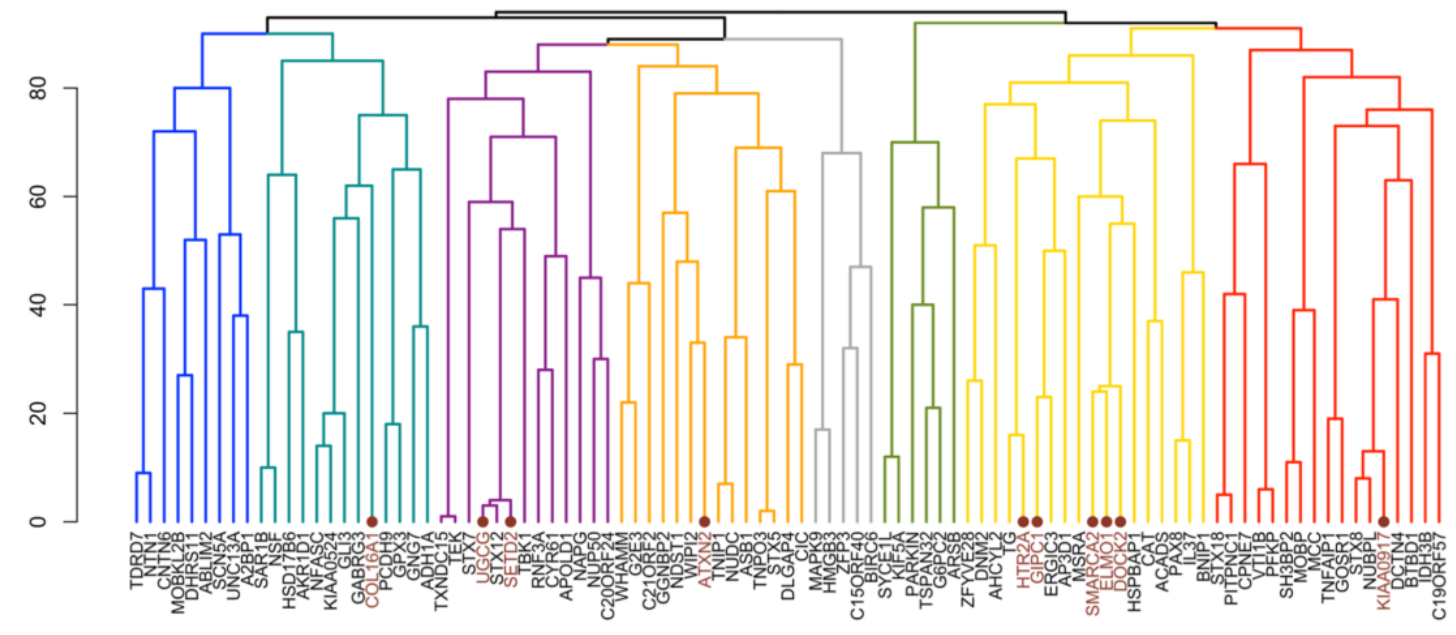


bioRxiv preprint doi: https://doi.org/10.1101/505693; this version posted February 24, 2019. The copyright holder for this preprint (which was not certified by peer review) is the author/funder, who has granted bioRxiv a license to display the preprint in perpetuity. It is made available under aCC-BY-NC-ND 4.0 International license.

Fig. 5: Biological pathways associated with the ALS co-expression subnetworks. a,

Biological pathways associated with each subnetwork of the ALS co-expression network

classified using FUMA (http://fuma.ctglab.nl/). b, Neuron-specific biological pathways

associated with each subnetwork also classified using FUMA.

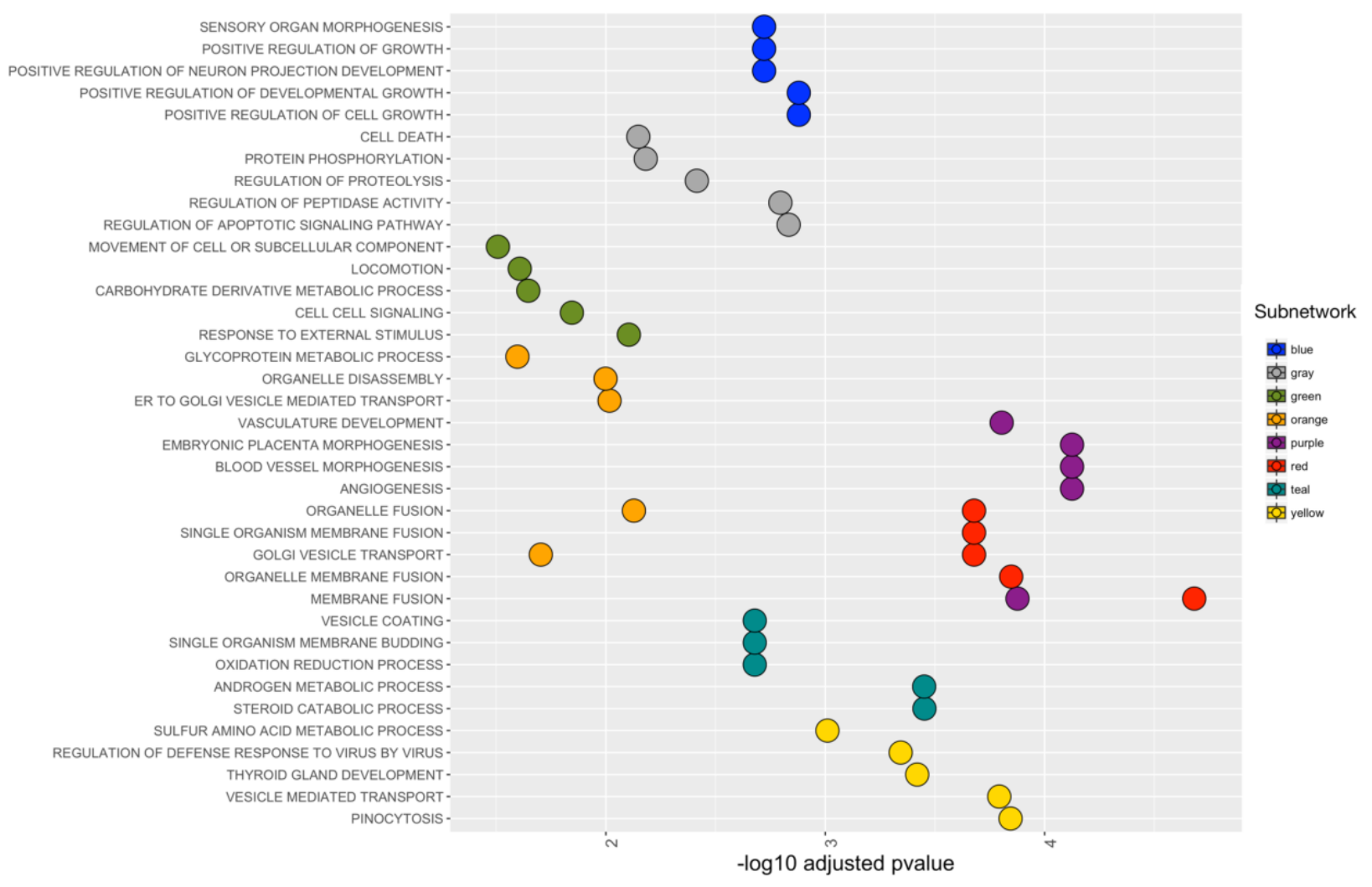


bioRxiv preprint doi: https://doi.org/10 1101/505693; this version posted February 24,2019 . The copyright holder for this preprint (which was not certified by peer review) is the author/funder, who has granted bioRxiv a license to display the preprint in perpetuity. It is made available under aCC-BY-NC-ND 4.0 International license.

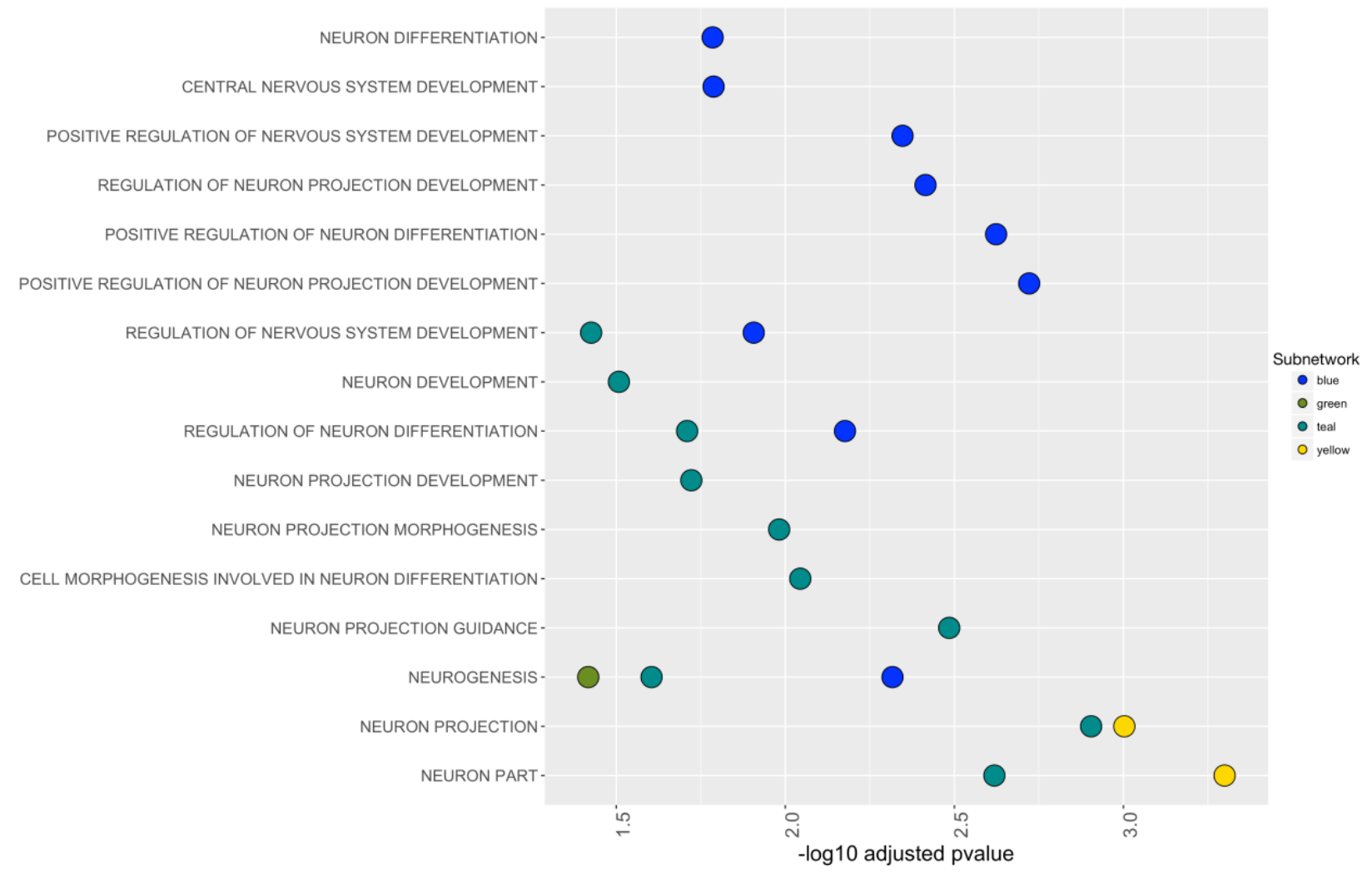


Fig. 6: Differential expression of ALS risk genes in diseased tissue. a, Differential expression of ALS risk genes in tissues of patients with ALS. b, Differential expression of ALS risk genes in SOD1 G93A transgenic mouse.
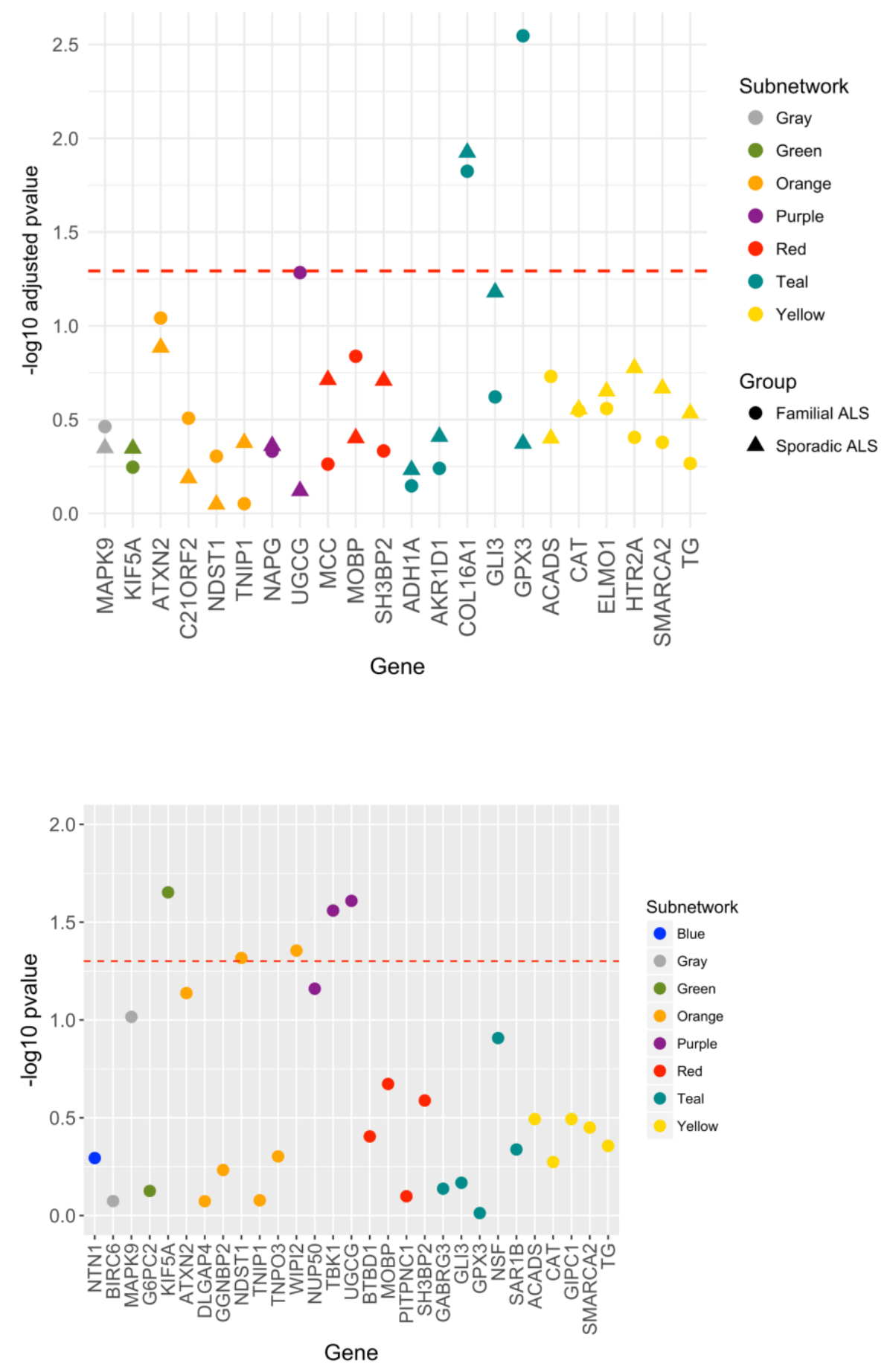
Table 1

\begin{tabular}{|c|c|c|c|c|c|c|c|c|c|}
\hline Disease/Trait & $\begin{array}{l}\text { Pleiotropic } \\
\text { SNP }\end{array}$ & $\begin{array}{l}\text { Closest } \\
\text { Gene }\end{array}$ & $\mathrm{Chr}$ & Position & $\begin{array}{c}\text { ALS } \\
\text { p-value }\end{array}$ & $\begin{array}{c}\text { Min } \\
\text { CondFDR }\end{array}$ & $\begin{array}{l}\text { Previously } \\
\text { Reported } \\
\text { SNPs in LD }\end{array}$ & $\begin{array}{l}\text { Other SNPs } \\
\text { within Gene }\end{array}$ & Citation \\
\hline VNR & rs10914464 & COL16A1 & 1 & 32132319 & $1.26 \mathrm{E}-04$ & $4.54 \mathrm{E}-02$ & Novel & & \\
\hline $\mathrm{HV}$ & rs10443173 & COL24A1 & 1 & 86533754 & $8.20 \mathrm{E}-06$ & $8.11 \mathrm{E}-03$ & Novel & & \\
\hline PSP & rs2068667 & NFASC & 1 & 204917680 & 3.39E-04 & $3.16 \mathrm{E}-02$ & rs 2068667 & & [8] \\
\hline FTD & rs515342 & ASB1 & 2 & 239367296 & $6.22 \mathrm{E}-04$ & $3.71 \mathrm{E}-02$ & rs515342 & & [8] \\
\hline ADHD & rs896444 & $\begin{array}{l}\mathrm{BC} 038566 \\
\text { (NCK2) }\end{array}$ & 2 & 106241808 & $1.32 \mathrm{E}-04$ & $3.89 \mathrm{E}-02$ & Novel & & \\
\hline $\mathrm{TC}$ & rs6737916 & BIRC6 & 2 & 32597985 & $2.82 \mathrm{E}-05$ & $2.81 \mathrm{E}-02$ & Novel & & \\
\hline NEUR & rs181357866 & CRIM1 & 2 & 35863487 & $3.10 \mathrm{E}-05$ & $1.92 \mathrm{E}-02$ & Independent & rs139895660 & [38] \\
\hline $\mathrm{T} 2 \mathrm{D}$ & rs13387347 & G6PC2 & 2 & 169754846 & $2.95 \mathrm{E}-05$ & $3.52 \mathrm{E}-02$ & Novel & & \\
\hline BMI & rs7602576 & IL37 & 2 & 113699617 & $6.79 \mathrm{E}-05$ & $4.80 \mathrm{E}-02$ & Novel & & \\
\hline LUNG & rs11695294 & LOC375295 & 2 & 177473618 & 5.12E-05 & $1.62 \mathrm{E}-02$ & Novel & & \\
\hline
\end{tabular}




\begin{tabular}{|c|c|c|c|c|c|c|c|c|c|c|}
\hline 11 & SMOKEONSET & rs13417671 & $\begin{array}{l}\text { TMP LOCUS } 39 \\
\text { (RASGRP3) }\end{array}$ & 2 & 34043426 & $1.04 \mathrm{E}-05$ & $1.36 \mathrm{E}-02$ & Novel & & \\
\hline 12 & EVERSMOKE & rs 17042645 & CNTN6 & 3 & 1731848 & $1.26 \mathrm{E}-04$ & $2.45 \mathrm{E}-02$ & rs 149853584 & & [7] \\
\hline 13 & BMI & rs 11718653 & HSPBAP1 & 3 & 122477858 & $9.41 \mathrm{E}-06$ & $6.15 \mathrm{E}-03$ & Novel & & \\
\hline 14 & PSP & rs9820623 & MOBP & 3 & 39493858 & $1.64 \mathrm{E}-05$ & $1.89 \mathrm{E}-03$ & rs 13079368 & $\begin{array}{c}\text { rs } 1768208 \\
\text { rs616147 }\end{array}$ & $\begin{array}{l}{[8]} \\
{[5]} \\
{[7]}\end{array}$ \\
\hline 15 & $\mathrm{~T} 2 \mathrm{D}$ & rs111970477 & SETD2 & 3 & 47105581 & $6.55 \mathrm{E}-05$ & $3.76 \mathrm{E}-02$ & Novel & & \\
\hline 16 & MDD & rs10938692 & ABLIM2 & 4 & 8118561 & $2.57 \mathrm{E}-05$ & $4.21 \mathrm{E}-02$ & Novel & & \\
\hline 17 & $\mathrm{AD}$ & rs1159918 & ADH1A & 4 & 100243009 & $1.98 \mathrm{E}-05$ & $7.39 \mathrm{E}-03$ & Novel & & \\
\hline 18 & ALC & rs 78710307 & $\begin{array}{l}\text { BC034799 } \\
(\text { LOC } 105377671)\end{array}$ & 4 & 59983437 & $1.07 \mathrm{E}-04$ & $4.32 \mathrm{E}-02$ & Novel & & \\
\hline 19 & VNR & rs 12646225 & RNF3A & 4 & 696848 & $1.51 \mathrm{E}-04$ & $4.91 \mathrm{E}-02$ & Novel & & \\
\hline 20 & BREAST & rs430979 & SH3BP2 & 4 & 2814698 & $2.41 \mathrm{E}-06$ & $1.40 \mathrm{E}-03$ & Novel & & \\
\hline 21 & VNR & rs 10011222 & SLC10A7 & 4 & 147441065 & $1.00 \mathrm{E}-04$ & $3.84 \mathrm{E}-02$ & Novel & & \\
\hline
\end{tabular}




\begin{tabular}{|c|c|c|c|c|c|c|c|c|c|c|}
\hline 22 & INSOMNIA & rs61789437 & ZFYVE28 & 4 & 2315630 & $2.08 \mathrm{E}-06$ & $9.40 \mathrm{E}-03$ & Novel & & \\
\hline 23 & SCZ & rs34384833 & $\begin{array}{l}\text { AK056485 } \\
\text { (GCNT4) }\end{array}$ & 5 & 91238155 & $1.65 \mathrm{E}-05$ & $2.50 \mathrm{E}-02$ & rs6453104 & & [39] \\
\hline 24 & CRP & rs 7735726 & ERGIC1 & 5 & 172347823 & $1.91 \mathrm{E}-05$ & $7.56 \mathrm{E}-03$ & rs538622 & & {$[8]$} \\
\hline 25 & CHRONOTYPE & rs 10050775 & GDNF & 5 & 38008042 & $1.00 \mathrm{E}-05$ & 3.61E-02 & Novel & & \\
\hline 26 & $\mathrm{CeD}$ & rs3828599 & $\begin{array}{l}\text { GPX3 } \\
\text { (TNIPI) }\end{array}$ & 5 & 150401796 & $2.45 \mathrm{E}-06$ & $5.85 \mathrm{E}-04$ & $\begin{array}{c}\text { rs10463311 } \\
\text { rs3828599 }\end{array}$ & & $\begin{array}{c}{[40]} \\
{[7]} \\
{[8]} \\
{[12]}\end{array}$ \\
\hline 27 & RT & rs35318094 & MAPK9 & 5 & 179672984 & $1.07 \mathrm{E}-05$ & $3.53 \mathrm{E}-02$ & Novel & & \\
\hline 28 & WHR & rs 17326496 & MCC & 5 & 112676579 & $5.79 \mathrm{E}-05$ & $1.70 \mathrm{E}-02$ & Novel & & \\
\hline 29 & VNR & rs 10463311 & NAF1 & 5 & 150410835 & $7.85 \mathrm{E}-07$ & $6.47 \mathrm{E}-03$ & Independent & rs17111695 & $\begin{array}{c}{[8]} \\
{[40]}\end{array}$ \\
\hline 30 & LUNG & rs150949995 & NDST1 & 5 & 149898499 & $4.13 \mathrm{E}-06$ & $1.01 \mathrm{E}-02$ & Novel & & \\
\hline 31 & PD & rs 7728741 & SAR1B & 5 & 133942492 & $2.55 \mathrm{E}-04$ & $4.58 \mathrm{E}-02$ & Novel & & \\
\hline 32 & VITILIGO & rs4958888 & TNIP1 & 5 & 150472842 & $1.45 \mathrm{E}-05$ & $9.80 \mathrm{E}-03$ & Independent & rs10463311 & $\begin{array}{c}{[40]} \\
{[7]}\end{array}$ \\
\hline 33 & WHR & rs 1543705 & AK127472 & 6 & 127197108 & $1.92 \mathrm{E}-04$ & 4.43E-02 & Novel & & \\
\hline
\end{tabular}




\begin{tabular}{|c|c|c|c|c|c|c|c|c|c|c|}
\hline 34 & MDD & rs 145705679 & C6ORF15 & 6 & 31069749 & $1.34 \mathrm{E}-04$ & 4.30E-02 & Novel & & \\
\hline 35 & TG & rs 4333390 & PARKIN & 6 & 162330919 & 4.22E-05 & $1.45 \mathrm{E}-02$ & Independent & $\begin{array}{c}\text { rs16892673 } \\
\text { rs777468774 } \\
\text { rs956103217 } \\
\text { rs7740421 } \\
\text { rs7757630 } \\
\text { rs7764218 } \\
\text { rs6904956 } \\
\text { rs564053 } \\
\text { rs6931162 }\end{array}$ & $\begin{array}{l}{[41]} \\
{[42]}\end{array}$ \\
\hline 36 & CHRONOTYPE & rs651001 & TMEM170B & 6 & 11569402 & 3.57E-05 & $1.48 \mathrm{E}-02$ & Novel & & \\
\hline 37 & PUT & rs 141730255 & AKR1D1 & 7 & 137938550 & $5.24 \mathrm{E}-05$ & $1.63 \mathrm{E}-02$ & Novel & & \\
\hline 38 & SMOKEONSET & rs 17171046 & ELMO1 & 7 & 37477863 & $3.90 \mathrm{E}-05$ & $3.88 \mathrm{E}-02$ & Novel & & \\
\hline 39 & $\mathrm{COG}$ & rs141347161 & GLI3 & 7 & 42417313 & $3.03 \mathrm{E}-05$ & $2.69 \mathrm{E}-02$ & Novel & & \\
\hline 40 & PUT & rs 10488631 & TNPO3 & 7 & 128594183 & $2.60 \mathrm{E}-05$ & $7.66 \mathrm{E}-03$ & rs10488631 & & $\begin{array}{l}{[12]} \\
{[8]}\end{array}$ \\
\hline 41 & NEUR & rs8180839 & WIPI2 & 7 & 5239970 & $6.14 \mathrm{E}-05$ & $2.41 \mathrm{E}-02$ & Novel & & \\
\hline 42 & PROSTATE & rs6996532 & BC045738 & 8 & 2417678 & $2.52 \mathrm{E}-06$ & $2.82 \mathrm{E}-03$ & rs17070492 & rs7813314 & $\begin{array}{c}{[7]} \\
{[8]} \\
{[43]} \\
{[5]}\end{array}$ \\
\hline
\end{tabular}


Novel

46 MDD

rs117204439 C9ORF72

9

$27607973 \quad 2.67 \mathrm{E}-10 \quad 2.78 \mathrm{E}-07$

rs222538

rs 774352
rs774351

rs903603

rs2814707

rs3849942

rs774359

rs 1752784

rs2782931 


\begin{tabular}{|c|c|c|c|c|c|c|c|c|c|c|}
\hline 47 & FTD & rs895021 & $\begin{array}{l}\text { MOB3B } \\
(\text { MOBKL2B) }\end{array}$ & 9 & 27484911 & $6.02 \mathrm{E}-17$ & 7.38E-09 & $\begin{array}{c}\text { rs3849943 } \\
\text { rs3849941 } \\
\text { rs } 2477523 \\
\text { rs2453555 } \\
\text { rs774352 } \\
\text { rs774351 } \\
\text { rs3849942 } \\
\text { rs2814707 } \\
\text { rs774359 } \\
\text { rs } 7019847\end{array}$ & & $\begin{array}{c}{[8]} \\
{[48]} \\
{[5]} \\
{[46]} \\
{[47]}\end{array}$ \\
\hline 48 & ALC & rs7024326 & SMARCA2 & 9 & 1903397 & $1.86 \mathrm{E}-05$ & $3.28 \mathrm{E}-02$ & Novel & & \\
\hline 49 & PSOR & rs7041171 & UGCG & 9 & 114701630 & $2.78 \mathrm{E}-05$ & $4.72 \mathrm{E}-02$ & Novel & & \\
\hline 50 & CBD & rs7944397 & CAT & 11 & 34455309 & $1.14 \mathrm{E}-05$ & 8.81E-03 & rs 12803540 & rs7118388 & [8] \\
\hline 51 & INTELLIGENCE & rs71472777 & ENDOGENOUS & 11 & 24142935 & $1.34 \mathrm{E}-05$ & $2.54 \mathrm{E}-02$ & Novel & rs 12361953 & $\underline{\text { LUPZP2 in AD }}$ \\
\hline 52 & $\mathrm{BPD}$ & rs 140988250 & $\mathrm{HCCA} 2$ & 11 & 1489420 & $1.27 \mathrm{E}-05$ & $3.51 \mathrm{E}-02$ & Novel & & \\
\hline 53 & CRP & rs12369156 & ACADS & 12 & 121167675 & 7.70E-06 & $1.98 \mathrm{E}-03$ & Novel & & \\
\hline 54 & SCZ & rs 117704471 & APOLD1 & 12 & 12904565 & $7.20 \mathrm{E}-05$ & $3.91 \mathrm{E}-02$ & Novel & & \\
\hline
\end{tabular}


rs739496

rs 10849949

rs2073950

rs2301621

rs6490162

rs628825

rs63051

rs616513

rs 12369009

rs695872

rs695871

TBK1

64881967

7.07E-07

2.68E-03

rs74654358

rs75209514

rs76805704

rs41292021

rs55824172

rs149881816

rs56196591

rs34774243

rs 145905497

rs 138369490

rs 17857028

rs138839127

rs 142030898

rs35635889

rs 144424516

rs 151225287

rs139195702

rs186475789

rs 141727722

rs 144370662

rs 187122554

rs185524052

Novel

\section{[5]}

[50]

[51]

[41] 


\begin{tabular}{|c|c|c|c|c|c|c|c|c|c|c|}
\hline 58 & PUT & rs 113247976 & KIF5A & 12 & 57975700 & $1.17 \mathrm{E}-05$ & $2.45 \mathrm{E}-02$ & rs113247976 & $\begin{array}{l}\text { rs117027576 } \\
\text { rs118082508 } \\
\text { rs116900480 } \\
\text { rs142321490 }\end{array}$ & $\begin{array}{c}{[53]} \\
{[7]}\end{array}$ \\
\hline 59 & BIP & rs 144387708 & $\begin{array}{l}\text { LOC144742 } \\
\text { (HSPB8, } \\
\text { HSP22) }\end{array}$ & 12 & 119702200 & $4.58 \mathrm{E}-06$ & $3.27 \mathrm{E}-02$ & Novel & $\begin{array}{l}\text { rs104894345 } \\
\text { rs104894351 }\end{array}$ & \\
\hline 60 & CBD & rs 1578303 & HTR2A & 13 & 47963146 & $9.55 \mathrm{E}-05$ & $3.63 \mathrm{E}-02$ & rs 1578303 & & [8] \\
\hline 61 & EXTRA & rs 10492593 & PCDH9 & 13 & 67494117 & $2.73 \mathrm{E}-05$ & $2.64 \mathrm{E}-02$ & Independent & $\begin{array}{l}\mathrm{rs} 35892541 \\
\mathrm{rs} 10492593\end{array}$ & $\begin{array}{c}{[54]} \\
{[8]}\end{array}$ \\
\hline 62 & SCZ & rs6420358 & SLITRK1 & 13 & 85289468 & $5.84 \mathrm{E}-05$ & $3.35 \mathrm{E}-02$ & Novel & & \\
\hline 63 & SWB & rs 17446243 & TTL/TEL & 13 & 40748931 & $1.17 \mathrm{E}-05$ & $3.41 \mathrm{E}-03$ & rs 17446243 & & [8] \\
\hline 64 & ADHD & rs447614 & $\begin{array}{l}\text { G2E3 } \\
\text { KIAA0917 }\end{array}$ & 14 & 31080799 & $1.97 \mathrm{E}-05$ & $5.47 \mathrm{E}-03$ & rs10139154 & rs 179552 & $\begin{array}{c}{[5]} \\
{[43]} \\
{[7]}\end{array}$ \\
\hline 65 & PD & rs 12886280 & NUBPL & 14 & 32298659 & $3.31 \mathrm{E}-06$ & $2.18 \mathrm{E}-02$ & rs 12886280 & & {$[8]$} \\
\hline 66 & MENOPAUSE & rs 2381030 & BTBD1 & 15 & 83741876 & $2.35 \mathrm{E}-05$ & $1.64 \mathrm{E}-02$ & rs6603044 & & [8] \\
\hline 67 & PROSTATE & rs 1877240 & FSD2 & 15 & 83438878 & $1.04 \mathrm{E}-05$ & 4.37E-02 & Novel & & \\
\hline
\end{tabular}




\begin{tabular}{|c|c|c|c|c|c|c|c|c|c|c|}
\hline 68 & CHRONOTYPE & rs3098553 & GABRG3 & 15 & 27876256 & $2.85 \mathrm{E}-05$ & $3.82 \mathrm{E}-02$ & rs3097439 & & [7] \\
\hline 69 & VNR & rs7193729 & A2BP1 & 16 & 7145869 & $1.19 \mathrm{E}-04$ & $4.76 \mathrm{E}-02$ & Independent & rs1551960 & [55] \\
\hline 70 & ADHD & rs56024498 & AK057218 & 16 & 76927135 & $8.24 \mathrm{E}-05$ & $3.46 \mathrm{E}-02$ & Novel & & \\
\hline 71 & ICV & rs62068675 & CPNE7 & 16 & 89648291 & $1.51 \mathrm{E}-04$ & 4.81E-02 & Independent & rs74213330 & [45] \\
\hline 72 & AGREE & rs192688752 & PKD1L2 & 16 & 81152628 & $2.43 \mathrm{E}-05$ & 3.63E-02 & Novel & & \\
\hline 73 & VNR & rs9903355 & $\begin{array}{l}\text { GGNBP2 } \\
\text { DHRS11 } \\
\text { PIGW }\end{array}$ & 17 & 34937221 & 4.93E-06 & $1.99 \mathrm{E}-03$ & rs 2285642 & & [8] \\
\hline 74 & CAD & rs35714695 & $\begin{array}{l}\text { KIAA0524 } \\
\text { (SARM1) }\end{array}$ & 17 & 26719788 & $1.16 \mathrm{E}-08$ & $5.75 \mathrm{E}-06$ & $\begin{array}{c}\text { rs739439 } \\
\text { rs35714695 }\end{array}$ & & $\begin{array}{l}{[8]} \\
{[5]} \\
{[7]}\end{array}$ \\
\hline 75 & $\mathrm{SCZ}$ & rs 2240601 & MSI2 & 17 & 55751112 & 4.82E-05 & $2.89 \mathrm{E}-02$ & rs2240601 & & {$[8]$} \\
\hline 76 & PSP & rs7224296 & NSF & 17 & 44800046 & $5.78 \mathrm{E}-04$ & 4.94E-02 & rs7224296 & & [8] \\
\hline 77 & ASD & rs9894834 & NTN1 & 17 & 9129028 & $8.16 \mathrm{E}-05$ & $2.83 \mathrm{E}-02$ & Novel & & \\
\hline 78 & HDL & rs 11652752 & PITPNC1 & 17 & 65375892 & $7.01 \mathrm{E}-05$ & $2.93 \mathrm{E}-02$ & rs11652752 & & $\begin{array}{c}{[56]} \\
(\operatorname{chr} 17: 65373923- \\
65689644)\end{array}$ \\
\hline
\end{tabular}




\begin{tabular}{|c|c|c|c|c|c|c|c|c|}
\hline 79 & ALC & rs7209200 & ZFP3 & 17 & 4969940 & $6.44 \mathrm{E}-05$ & $3.75 \mathrm{E}-02$ & Novel \\
\hline 80 & $\mathrm{HV}$ & rs 17187386 & DOK6 & 18 & 67196957 & $6.19 \mathrm{E}-05$ & $2.76 \mathrm{E}-02$ & Novel \\
\hline 81 & BREAST & rs 12967284 & SPIRE1 & 18 & 12532098 & $1.62 \mathrm{E}-05$ & $3.31 \mathrm{E}-02$ & Novel \\
\hline 82 & OPEN & rs112183647 & GIPC1 & 19 & 14612725 & $2.25 \mathrm{E}-05$ & $4.26 \mathrm{E}-02$ & Novel \\
\hline 83 & BPD & rs7258235 & GNG7 & 19 & 2612118 & $1.38 \mathrm{E}-05$ & $2.70 \mathrm{E}-02$ & Novel \\
\hline 84 & FTD & rs 12608932 & UNC13A & 19 & 17752689 & $1.91 \mathrm{E}-08$ & $1.28 \mathrm{E}-06$ & $\begin{array}{l}\text { rs78549703 } \\
\text { rs12608932 }\end{array}$ \\
\hline 85 & PD & rs6015322 & APCDD1L & 20 & 57206540 & $6.30 \mathrm{E}-05$ & 4.09E-02 & rs6015322 \\
\hline 86 & FTD & rs 2425220 & DLGAP4 & 20 & 34999440 & $1.30 \mathrm{E}-04$ & $3.06 \mathrm{E}-02$ & rs2425220 \\
\hline 87 & NEUR & rs9653747 & ВС028044 & 21 & 20041418 & $4.34 \mathrm{E}-06$ & 4.33E-03 & Novel \\
\hline 88 & VNR & rs75087725 & $\mathrm{C} 21 \mathrm{ORF} 2$ & 21 & 45753117 & $7.52 \mathrm{E}-11$ & $1.65 \mathrm{E}-07$ & rs75087725 \\
\hline 89 & AGREE & rs2176039 & NUP50 & 22 & 45585032 & $8.98 \mathrm{E}-05$ & $3.82 \mathrm{E}-02$ & rs2176039 \\
\hline
\end{tabular}

